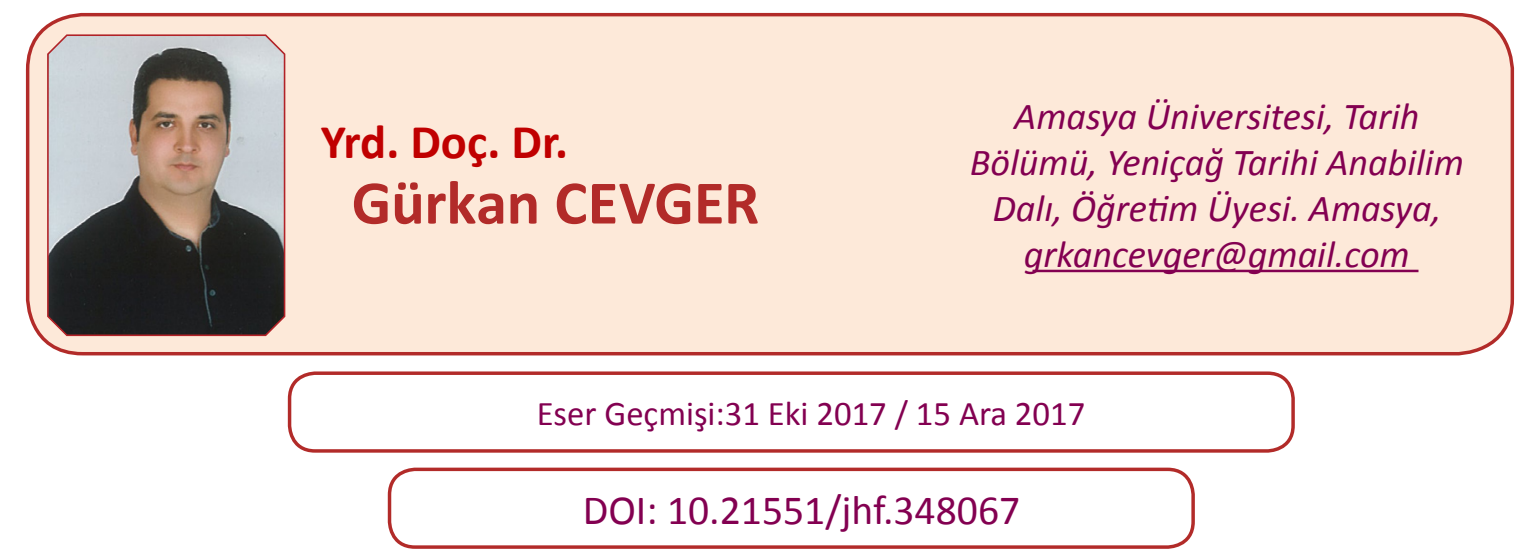

\title{
Ahkâm Defterlerine Göre 18. Yüzyılda Amid Kazâsı'nda Gündelik Yaşamı Etkileyen Şikâyet Konuları (1700-1800)
}

\author{
Ahkâm Defters by the Complaints Considerations of the Daily Life in \\ the 18th Century in the Amid District (1700-1800)
}

\section{ÖZET}

Ahkâm Defterleri, temelde halkın şikâyet ve problemlerini çözüme kavuşturmak ve adaleti tesis etmek amacıyla tutulmuştur. Osmanlı bürokrasisinde 16 eyâlet adına tutulan bu defterlerden birisi de Diyarbekir Eyaleti adına düzenlenmiştir. Bu defterlerde, başta Amid olmak üzere Mardin, Çemişgezek, Harput, Siverek, Hasankeyf, Ergani, Siirt, Çapakçur, Tercil, Kulp, Çermik, Pertek, Sincar, Atak, Musul, Palu, Eğil gibi sancaklara dair şikâyet kayıtları bulunmaktadır. Bu defterlerden Amid sancağının idari merkezi olan Amid kazâsı ve kazâya bağlı nahiyelerden gelen şikâyetler yüz yıllık bir dönem içerisinde incelenmiş ve bu şikâyetler konularına göre tasnif edilerek çalışmada kullanılmıștır. 1700-1800 yılları arasında Amid kazâsı'nda yaşayan insanların en çok hangi konulardan şikâyet ettikleri, şikâyetlerin kazâ merkezinde mi, yoksa kırsalda mı daha fazla olduğu ve devletin bu şikâyetlere bulduğu çözümler bașta ahkâm defterlerine yansıdığı kadarıyla incelemeye tabi tutulmuş olup, ayrıca konunun desteklenmesi adına diğer arşiv vesikalarından da istifade edilmiştir. Böylece 18. yüzyıldaAmid halkının gündelik yaşamı aydınlatılmaya çalışılmıștır.

Anahtar Kelimeler: 18. Yüzyll, Diyarbakır Eyâleti, Ahkâm Defterleri, Amid kazâsı, Şikâyet.

\section{ABSTRACT}

AhkâmDefters are mainly held to solve the complaints and problems of the people and to establish justice. These defters held in the name of 16 provinces in the Ottoman bureaucracy was organized in the name of Diyarbakir Province. In these defters, there are complaint 
records about Amid banners such as Mardin, Çemişgezek, Harput, Siverek, Hasankeyf, Ergani, Siirt, Çapakçur, Tercil, Kulp, Çermik, Pertek, Sincar, Atak, Mosul, Palu and Eğil. From these books, complaints from Amid district and incarnations, which are the administrative center of the Amid Sanjack, were examined within a period of one hundred years and these complaints were classified according to their subjects and used in the study. Among the people who lived in Amid district between 1700 and 1800, the most complaints about the subjects, the complaints in the district center or the rural areas and the solutions that the state found in these complaints were examined to the extent that they were reflected in the defters of their chiefs. Archives and documents. Thus, in the 18th century, the daily life of the Amid people was tried to be illuminated.

Keywords: 18th Century, Diyarbakır Province, AhkâmDefters, Amid District, Complaint.

\section{Giriş}

Osmanlı İmparatorluğu'nda yaşayan köylü, asker, Müslüman, gayrimüslim herkesin bireysel veya toplu olarak şikâyet yani arz-ı hâl sunma hakkı bulunmaktaydı. ${ }^{1}$ Kişiler, adaletin sağlanması için şikâyetlerini rahatlıkla divan-ı hümayun'a sunabilmekte idiler. Halkın ve yöneticilerin şikâyetlerinin toplandığı ahkâm defterlerinde yöneten ve yönetilen arasındaki ilişkileri, kanunların ne ölçüde uygulandığı ve uygulama esnasında ne tür hukuki boşlukların doğduğu ve bu hukuki boşlukların toplum içerisinde ne gibi sorunlara sebep olduğunu görmek mümkündür.

18. yüzyılda Osmanlı Devleti'nin içinde bulunduğu ekonomik ve siyasi durum gerek devletin yönetim merkezinde, gerekse taşrada yaşayan halkı ciddi şekilde etkilemeye başlamıştır. Savaşların kaybedilmeye başlanması, ekonominin gün geçtikçe bozulması ve taşrada merkezi otoritenin gücünü zaman içerisinde kaybetmeye başlamasıyla yöneticiler ile halk arasındaki sorunlar da hızla artmıştır. Amid kazâsı gibi köklü tarihi geçmişi olan bir şehirde de 18. yüzyılda gündelik yaşamda halkın birbiriyle veya yöneticiler ile yaşadıkları farklı türden olayların olması kaçınılmazdır. Bu dönemdeAmid kazâ merkezi ve kazâya bağlı nahiyelerden gelen şikâyetlerin türü ve içeriğinin detaylı şekilde öğrenilmesi şehir ve bölge tarihinin aydınlatılması açısından önem arz etmektedir. XVIII. yüzyılın ikinci yarısında kazâ genelinde meydana gelen vergilerin tahsili ile ilgili sıkıntılar, alacak-verecek ilişkileri, toprak denetçisi sipahilerin halk ile olan çeşitli anlaşmazlıkları, toprak ve su anlaşmazlıkları, vergi veren halk ile vergiyi tahsil eden görevliler arasındaki anlaşmazlıklar, toprak anlaşmazlıklarında halk ve yönetici arasındaki anlaşmazlıklar, vakıflar ile ilgili sıkıntılar ve asayişi bozan çeşitli eylemler başta ahkâm-ı şikâyet kayıtları olmak üzere diğer arşiv vesikalarına da yansıdığı ölçüde incelenmiştir.

\section{Gündelik Yaşamda Meydana Gelen Olaylar}

İncelenen dönem içerisinde 1-5 numaralı Diyarbakır ahkâm defterlerindeki hükümler

1 Halil İnalcık, Osmanlılar Fütuhat, İmparatorluk, Avrupa İle İlişkiler, Timaş Yayınları, İstanbul 2010, s. 123. 
tek tek taranmış ve doğrudan Amid kazâsına ait olduğu belirlenen 567 şikâyet kaydı tespit edilebilmiştir. Bu şikâyetlerin konularına göre dağılımı aşağıda grafik halinde verilmiştir.2

Grafik.1.Amid kazâsı'nda Şikâyetlerin Konularına Göre Dağılımı ve Şikâyet Sayısı

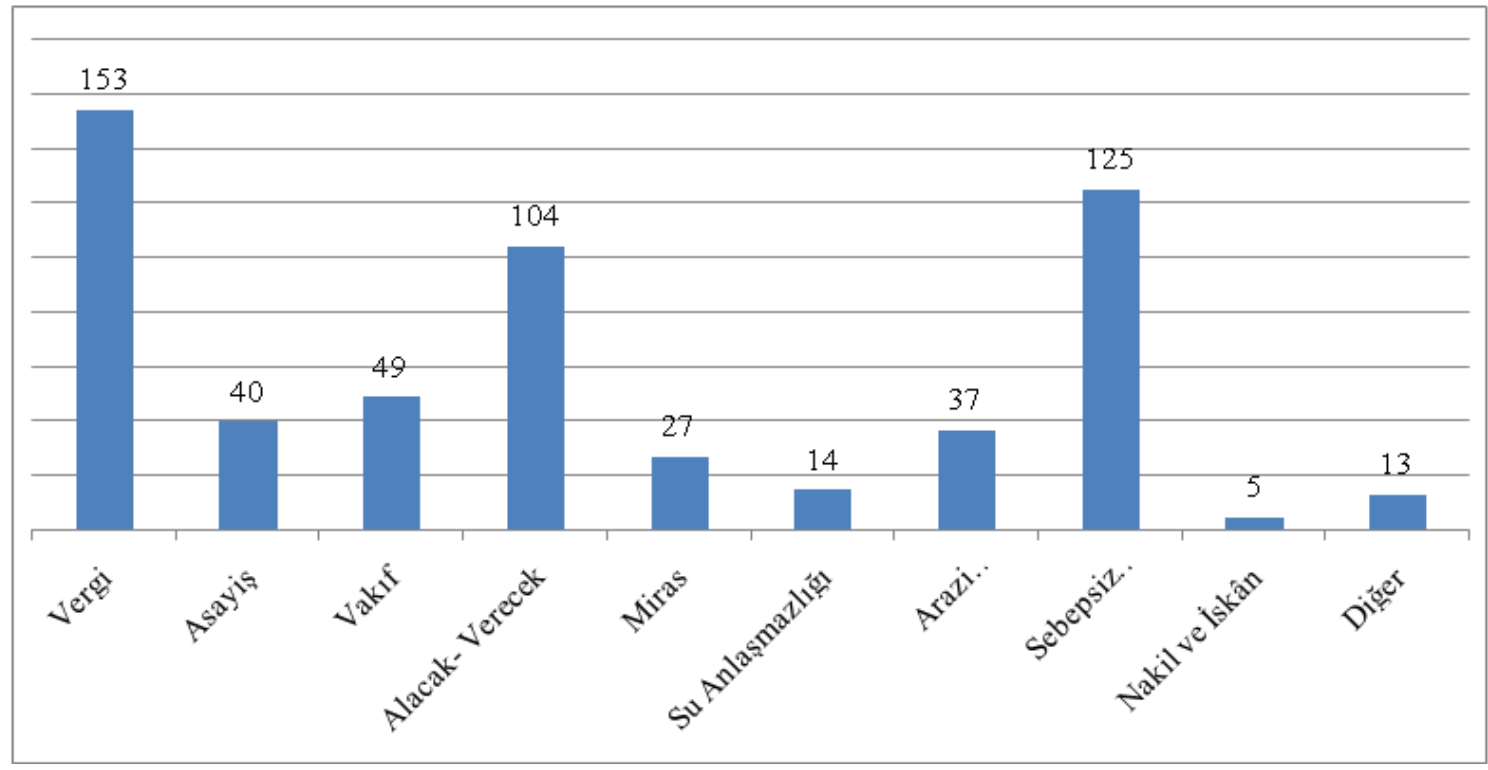

Yukarıdaki tabloda görüldügü üzere 153 şikâyet ile vergi konusu ilk sırada gelmektedir. İkinci sırada sebepsiz müdahale ve tacizler varken üçüncü sırada 104 şikâyet ile alacakverecek meseleleri dikkat çekmektedir. İncelenen dönem içerisinde en az şikâyetise 5 kayıt ile nakil ve iskân ile ilgilidir. Bu dönemde Amid kazâsı'nda meydana geldiği tespit edilebilen 567 şikâyet kaydının kazâ merkezi ve nahiyelere dağılımı şu şekildedir.

Grafik. 2.Amid kazâsı'nda Şikâyetlerin Kazâ Merkezi ve Nahiyelere Göre Dağılımı

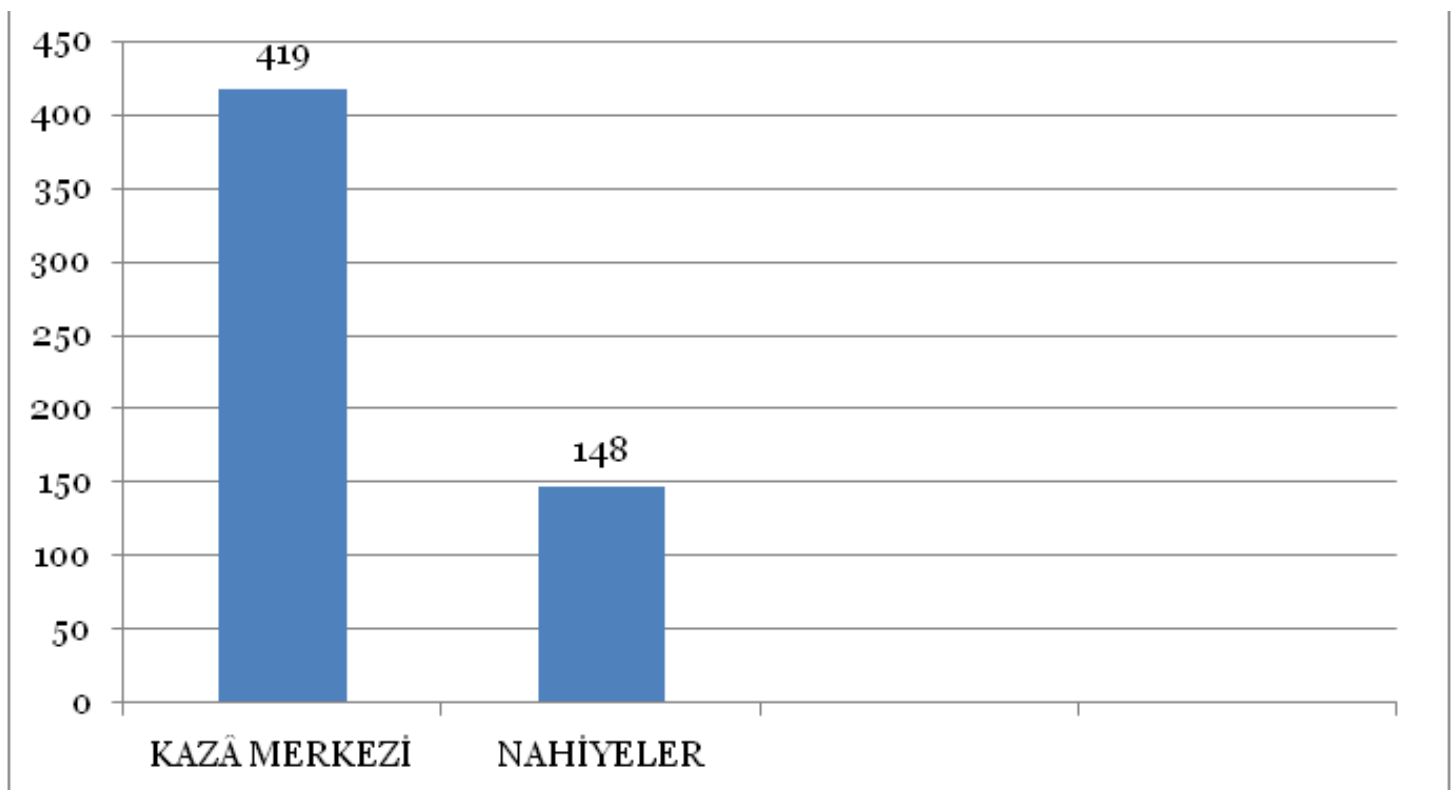

2 Grafik hazırlanırken makale başlığının ve ana kaynağın ahkâm defterleri olması nedeniyle ahkâm defterlerinin haricindeki arşiv vesikaları tabloya dâhil edilmemiştir. 
Yukarıdaki grafikte görüldüğü üzere kazâ genelinde meydana gelen şikâyet vakalarının büyük bir kısmı kazâ merkezinde gerçekleşmiştir. Bu duruma, kazâ merkezindeki nüfusun nahiyelere oranla daha fazla olması neden olmuş olmalıdır. Kazâ merkezindeki şikâyetlerde göreve müdahale, alacak-verecek meseleleri ve vergiler ilgili sorunlar ön plana çlkarken, nahiyelerde toprak mülkiyetine müdahale, su-arazi anlaşmazlıkları ile ilgili şikâyetler daha fazladır. İncelenen dönemde Amid kazâsı'nda meydana gelen olaylar ve şikâyet örnekleri aşağıda konularına göre değerlendirilmiştir.

\section{2-Asayişi Bozan Olaylar}

Amid kazâsı gibi sosyal-kültürel ve etnik çeşitliliğin fazla olduğu bir bölgede gündelik hayatta farklı türden olayların meydana gelmesi kaçınılmazdır. Bu olaylar içerisinde cinayet, gasp, yaralama, taciz etme gibi adlî olaylar, sicillere ve diğer arşiv kaynaklarına yansıdığı ölçüde incelenmeye tabi tutulmuştur. Amid kazâsı'nda gündelik hayatta meydana gelen olaylar verilen örnekler ile sınırlı olmayıp, mevcut belgeler ışığında genel bir fikir vermesi bakımından önemlidir. Gündelik yaşamda meydan gelen olaylar içerisinde cinayet vakaları önemli bir yer tutmaktadır. Arşiv kayıtlarına yansıdığı kadarıyla 18. yüzyılda kazâ merkezinde on üç cinayet vakası var iken, kırsalda meydana gelen dört cinayet olayı tespit edilebilmiştir.

Amid kazâsı halkından Osman adlı şahıs 13 Temmuz 1742 tarihinde divana şikâyette bulunarak, oğlu Feyzullah'ı zulüm ve eşkıyalık ile meşhur Alemdar Kasım ve Alemdar Mehmet adlı şahısların haksız yere öldürdüklerinden adaletin sağlanmasını talep etmiştir. ${ }^{3}$ Amid halkından Hasan, 4 Temmuz 1760 tarihinde divana arz-ı hâl sunarak, babası Hacı Hüseyin adlı şahısın kimseye bir kusuru ve müdahalesi yok iken, İsmail Ağa ve oğlu Hüseyin, Ahmet ve Hasan adlı şahısların babasını haksız yere öldürdüklerini söylemiştir. Bu olay üzerine cinayetin araştırılması için mübaşir tayin edilerek haksızlığın giderilmesine çalışılmıştır.4

Cinayet olaylarında cinayeti işleyen tek kişi olabildiği gibi bazen birçok kişinin bir araya gelerek suça iştirak ettiklerine dair kayıtlar da bulunmaktadır. Mesela Amid halkından Seyyid Ahmet, 15 Ekim 1794 tarihinde Dîvân-ı Hümâyûn'a müracaat ederek, babası Hacı Hasan’ın ve amcasının, Alikan ve Sinanlı Aşiretleri eşkıyalarından Mehmet Kethüda, Abdullah, Molla Hasan, Resul oğlu Ali ve Hüseyin adlı şahıslar tarafından öldürüldüklerinden şikâyet etmiştir. ${ }^{5}$ Seyyid Ahmet, babasının cinayetinin aydınlatılmadığı gibi Alikan ve Sinanlı Așiretleri eşkıyalarından bazı kimselerin kendisine taciz ve tehditlerinin devam ettiğini belirterek ve adaletin sağlanmasını istemiştir. ${ }^{6}$

Cinayet vakaları kazâ merkezinde olduğu gibi karye ve nahiyelerde de vuku bulabilmekteydi. Mesela Döğerli Aşireti'ne tabi Balaban Oymağı'ndan Murat oğlu Gazi 19 Mayıs 1723'de mahkemeye başvurarak, kız kardeşi Güzel adlı hanımın Amid kazâsı'na tabi Karacadağ'da bulunan Karacı Kuyusu adlı yerde hayvanlarına su vermek için kuyudan su çektiği esnada Bayki Aşireti'nden Resul oğlu Mehmet tarafından göğsüne taş ile vurularak

3 Başbakanlık Osmanlı Arşivi, Divan-1 Hümayun Sicilleri, Sivas Ahkâm Defterleri Defter 1, s. 2. Bu sonra BOA, DVNSAHK. DB. d.

4 BOA. A. DVNSAHK. DB. d. 2, s. 203.

5 BOA. A. DVNSAHK. DB. d. 5, s. 95.

6 BOA. A. DVNSAHK. DB. d. 5, s. 109. 
yaralandığını ve kız kardeșinin bu yara sebebiyle olay yerinde vefat ettiğini belirtmiștir. ${ }^{7}$ Yine Mustafa Paşa Mahallesi halkından Cemşid oğlu Resul, 7 Aralık 1746 tarihinde eskiden beri düşmanları olan Şark-i Amid Nahiyesi'ne bağlı Kadıkendi karyesinden Hızır ve babası Hasan oğlu Abdi ile Hızır'ın karyedeki bağında kavga ettiği ve kavga esnasında Hızır'ın kürek ile Resul'ün başına vurarak öldürdügünü iddia etmiștir. Bu sebeple maktul Resul'ün yakınları diyet talep etmişlerdir. ${ }^{8}$ Yaklaşı 5 ay sonra 9 Nisan 1747 tarihli başka kayıtta öldürüldüğünü söyledikleri Resul'ün varislerinin iddialarının yalan olduğunu itiraf etmeleri üzerine davanın düşmesine ve talep edilen diyetin reddine karar verilmiştir. ${ }^{9}$

Cinayet olaylarının neticesinde mağdur tarafın yakınları katilin kendinden veya yakınlarından diyet veya diyet-i kâmile ${ }^{10}$ adı altında para talep etmekteydiler. Mesela Çaruği Mahallesi halkından iken öldürülen İsmail oğlu Mehmet'in varisleri 20 Ocak 1741 tarihinde mahkemeye başvurarak, İsmail oğlu Mehmet'i öldüren Hacı Ömer'den 300 kuruş diyet parası istemişlerdir. Hacı Ömer 300 kuruşu varislere ödeyerek mahkeme huzurunda ödemiş ve iki taraf anlaşmışlardır. ${ }^{11}$

Cinayet vakalarının neticesinde haksız yere diyet talepleriyle ilgili kayıtlar da bulunmaktadır. Mesela İzzeddin Mahallesi halkından Ayșe Hanım 24 Kasım 1746 tarihinde mahkemeye başvurarak, kocası Hacı Kamber oğlu Abdulbaki'nin Süleyman oğlu Hamamcıŏlu Mehmet ve Mustafa oğlu Lüleci İbrahim tarafından öldürüldügünü iddia edip, ölen kocası için adı geçen şahıslardan diyet talep etmiştir. Ancak mahkemede cinayet iddiasında bulunan Ayşe Hanım'ın iddiasını ispat etmesini istemiş ancak Ayşe Hanım iddiasını ispatlayamamıștır. ${ }^{12}$ Cinayet iddiasının ispatı ile ilgili başka bir olayda Alican Mahallesi'nde sakin iken öldürülen Ömer oğlu Musa'nın varisi olan erkek kardeşi 29 Temmuz 1739 tarihinde mahkemeye başvurarak kardeşini Hocaoğlu Bekir ve Abdi adlı şahısların öldürdüğü iddia etmiştir. Mahkeme iddianın ispat edilmesini istemiș ancak iddia ispatlanamadığından dava düşmüștü. ${ }^{13}$

Osmanlı hukukunda çok eski zamanlardan beri uygulanmakta olan kasame ${ }^{14}$ müessesesinin Amid kazâsı'nda meydana gelen adlî olaylarda da etkin şekilde uygulandığına dair kayıtlar mevcuttur. Şeyhülislam Ebussuud Efendi'nin izah ve fetva ettiği üzere ${ }^{15}$ gündelik

7 Diyarbakır Şeriyye Sicilleri 313 s. 56. Bundan sonra DŞS.

8 DŞS. 313, s.130.

9 DŞS. 313, s.153.

10 Öldürülen şahsın nefsine bedel. Katilden veya ailesinden alınan tam diyet olup miktarı maktûle göre değişirdi. Hür olanın diyet-i kâmilesi yüz deve veya iki yüz sığır veya iki bin koyun ya da dengi paradır. Bu da bin dinar, on bin dirhem-i şer'i gümüștür. Esir veya cariye olmayan hür kadının ise yarısı olup, kölenin diyet-i kâmilesi kendi kıymetidir. Ali Bardakoğlu, "Diyet”, DİA, Türk Diyanet vakfi Yayınları, C.9, İstanbul 1994 s. 473-478.Mehmet Ali Ünal, Osmanlı Tarih Sözlüğü, Paradigma Yayınları, İstanbul 2011, s. 204, Ferit Devellioğlu, OsmanlıcaTürkçe Ansiklopedik Lûgat, Aydın Kitabevi, Ankara 2010, s. 215.

11 DŞS. 360, s. 203.

12 DŞS. 313, s. 136.

13 DŞS. 360, s. 328.

14 Köy, mahalle, yol veya Camii gibi umumi bir yerde yahut özel bir mülk üzerinde katil belirtileri bulunan bir ceset bulunması durumunda maktul veya maktulenin yakınlarının dava etmeleri üzerine söz konusu yerin halkından elli kişiye "vallahi biz onu öldürmedik, katilini de bilmiyoruz" şeklinde yemin ettirilmesi esasına dayanır. Yemin edilmesiyle birlikte öldürülen kişinin diyeti, cesedin bulunduğu yer özel mülk ise mülk sahibinin akilesine, umumi bir yer ise köy veya mahalle halkına ödettirilirdi. Aybars Pamir, "İslam ve Osmanlı Hukuku'nda Kasame Müessesesi”, Ankara Üniversitesi Hukuk Fakültesi Dergisi, 54(4), Ankara 2005, s. 343-344.

15 Mesele: Zeyd bir mağaranın içinde mecruhen maktul bulunup, mağaranın üzerinden şiddetle nida olundukta 
hayatta kasamenin uygulanmasında nasıl bir yol izlendiğine dair bir olayda Ali adlı şahıs, Garb-i Amid Nahiyesi'ne tabi Molla Davut Karyesi'nde 4 Nisan 1754 tarihinde ölü olarak bulunmuş ve "kimesnenin mülki olmayan yerde cebren katl olup katili mallûm olup kasame ve diyeti şer'an karye-i mezbûr ahâlîsine lazım gelmişken" karye ahalisi Ali'nin kasame diyetini ödemeye muhalefet etmişlerdir. ${ }^{16}$

Yukarıda verilen farklı türdeki cinayet vakalarının hepsinde devletin ve adliye makamındaki kimselerin meselenin çözülmesi ve adaletin yerini bulması için doğrudan olaya müdahale ettiği ayrıca merkezi hükümetin cinayet vakaları sebebiyle şikâyete gelen kişi veya kişilerin şikâyetlerini dikkate alarak olayların aydınlatılması için azami gayreti sarf ettiği arşiv belgelerinden anlaşılmaktadır.

Amid kazâsı'nda ve kırsalında meydana gelen adlî olaylardan bir diğeri de yaralama ve gasp olaylarıdır. Bu olaylar içerisinde bir kişinin yapmıș olduğu gasp ve yaralama olayları olabildiği gibi, birden fazla kişinin birleşip gerçekleştirdiği olaylar da mevcuttur. Kazâ merkezi ve karyelerden arşiv kayıtlarına yansıyan otuz olay tespit edilebilmiştir.

Kazâ merkezinde meydana gelen yaralama olaylarından bazıları şöyledir. Kılbaș Mahallesi halkından Ömer, Tomcan adlı zimmînin yanında 9 Eylül 1723 tarihinde çıraklık ederken, Ömer'in sol gözüne vurarak yaralamıștır. Ömer'in babası bu durum üzerine Tomcan'dan şikâyetçi olmuştur. Tomcan mahkeme esnasında çocuğu terbiye etmek niyetiyle vurduğunu söylemiştir. ${ }^{17}$ Kazâ merkezinde meydana gelen 9 Eylül 1723 tarihli başka bir olayda Nalçacı Mahallesi halkından Recep oğlu Hacı Halil adlı şahıs mahkemeye gelerek, Yusuf oğlu Halil Çelebi'nin elindeki tabancanın patlaması ile dişlerinin ve çene kemiğinin kırıldığını bildirmiștir. Ancak olayın bir kaza neticesinde meydana geldiğini Yusuf oğlu Halil Çelebi ile bir Mushaf-ı Şerif, bir kılıç ve elli kuruş karşılığında sulh ettiklerini beyan etmiştir. ${ }^{18}$ Amid halkından Seyyid Ömer, 20 Temmuz 1764'de Dîvân-ı Hümâyûn'a şikâyette bulunarak, kız kardeşi Fatma Hanım'ı, Diyarbekir valisi Veli Paşa'nın kâtibi olan Osman’ın tüfek ile yaraladığını bildirerek zulüm ve haksızlı̆̆ın giderilmesini istemiştir. ${ }^{19}$

Karyelerde meydana gelen olaylardan bazıları șu șekildedir. Şark-i Amid Nahiyesi'ne tabi Salat Karyesi'nden Ömer, 28 Temmuz 1724'de mahkemeye başvurarak, İbrahim oğlu Mustafa tarafından başına kılıç ile vurulduğunu, kardeșinin de sol kolundan yaralandığını söyleyerek İbrahim oğlu Mustafa'dan şikâyetçi olmuştur. ${ }^{20}$ Karyelerde meydana gelen olaylara başka bir örnekte, Garb-i Amid Nahiyesi'ne bağlı Hacıruz Karyesi halkından Resul oğlu Seyyid 31 Ekim 1746 tarihinde mahkemeye başvurarak, oğlu Mustafa'nın Ali oğlu Ömer adlı şahıs tarafından kılıç ile boynuna ve sol kulağı üzerine vurularak yaralandığını söyleyerek şikâyetçi olmuştur.

karyeye avaz işidilir yerde olsa, mezbûre karye ahalisine diyet lazım olur mu? El-Cevap: Olur. Mesele: Bir kasaba kurbundaZeyd maktul bulunup katili malum olmayıp, avaz cümle kasabaya işidilir olsa diyeti cümle kasaba ahalisine mi lazım olur. Yoksa ol tarafta olan mahalle ehline mi? El-Cevap: Kurbunun ehline lazım olur. Ertuğrul Düzdağ, Kanuni Devri Şeyhülislamı Ebussuud Efendi Fetvaları, Kapı Yayınları İstanbul 2012, s. 199.

16 BOA. A. DVNSAHK. DB. d.1, s. 271.

17 DŞS. 592, s.13.

18 DŞS. 592, s.14.

19 BOA. A. DVNSAHK. DB. d.3, s. 58.

20 DSS. 352, s. 9. 
Mahkeme şahitlerin ifadelerine binaen Ali oğlu Ömer'i suçlu bulmuştur. ${ }^{21}$

Kazâ merkezi ve karyelerde meydana gelen ve asayişi bozan bir diğer vaka gasptır. Bu olaylar içerisinde para gaspı ile birlikte, farklı mal ve eşya gasplarına da rastlanmaktadır. Bu olaylar ile ilgili ahkâm-ı şikâyet kayıtlarında oldukça fazla örnek bulunmaktadır. Mesela Amid halkından Seyyid Mehmet adlı şahıs 31 Mayıs 1794 tarihinde dîvân-ı hümâyûn'a müracaat ederek, kendisinin kimseye zararı ve kusuru yok iken Amid kazâsı halkından Osman ve Muhaciroğlu adlı şahısların haksız şekilde evini bastıklarını, evinde bulunan 500 kuruşluk eşyasını ve bir miktar parasını gasp ettiklerini söyleyerek, gasp edilen mal ve parasının geri alınmasını talep etmiștir. ${ }^{22}$ Ticaret amacıyla Amid kazâsı dışından geçen Karagöz, Semo ve Arbin adlı zimmîler 11 Ekim 1750 tarihinde Amid halkından Veli, Ramazan ve Karaoğlu adlı şahısların eşkıya ile bir olarak kendilerine saldırması sonucu gasp edilmişlerdir. ${ }^{23}$

Kazâda cereyan eden gasp olayları sadece mal ve eşyalar ile sınırlı değildir. Bu dönemde kazâda yaşayan kişilerin mülkiyetinde olan hayvanların veya tarladaki mahsullerinin bazı kimseler tarafından gasp edildiğine dair vakalar da bulunmaktadır. Mesela Amid halkından Molla İbrahim ve Süleyman divana müracaat ederek, Amid halkından Ali ve Süleyman adlı şahısların hiçbir hukuki gerekçe göstermeden kendilerine ait 1400 koyunlarını haksız şekilde gasp ettiklerini söyleyip şikâyetçi olmuşlardır. Ali ve Süleyman tarafından gasp edilen koyunlarının taraflarına alınması için Diyarbekir valisine ve Amid kadısına hüküm yazılmıștır. ${ }^{24}$ Yine Amid sakinlerinden Mehmet, 24 Şubat 1763'de Dîvân-ı Hümâyûna şikâyette bulunarak, sahibi olduğu at, eșek, öküz ve koyunlarının Yusuf, Ebubekir ve Bali Ömer oğlu Mehmet adlı kimseler tarafından gasp edildiğini, hayvanlarının kendisine iade edilmesini ve adaletin sağlanmasını istemiștir. ${ }^{25}$ Amid kazâsı'ndan Mustafa 24 Ocak 1793'de dîvân-ı hümâyûna müracaat ederek, kendisinin kimseye düşmanlığı ve borcu yok iken Amid halkından Bekir adlı şahıs hiçbir gerekçe göstermeden altmış kuruş kıymetli mahsulünü "cebren ahz-u kabz gasp ve garet eylediğinden" mahsulünün kendisine alınmasını istemiștir. ${ }^{26}$

İncelenen dönemde Amid kazâsı'nda meydana gelen yaralama olaylarının bazıları kasten yaralama iken, bazı olaylar kaza sonucu meydana gelen olayları ihtiva etmektedir. Devlet, kasten yaralama olaylarında adaletin sağlanması için azami çaba göstermektedir. Kaza sonucu meydana gelerek kişi veya kişilerin yaralanmalarına sebep olan olaylarda genellikle şahısların kendi aralarında para veya eşya vermek suretiyle barış yolunu tercih ettikleri görülmektedir. Amid kazâsı'nda meydana gelen gasp olaylarında halkın adaletin tesisi için mahkemeye veya divana başvurduğu gasp edilen mallarını geri almak için ilk olarak hukuki yolları tercih ettikleri anlaşılmaktadır.

Bu dönemde kazâ merkezi ve kırsalda meydana gelen ve asayişi bozan diğer bir eylem eşkıyalıktır. Eşkıyalık hareketleri tarih boyunca zor kullanarak, insanların mallarına el koyma, bunu gerçekleştirebilmek için hayatlarına kastetme, onlara maddi ve manevi zararlar vererek

21 DŞS. 313, s. 111.

22 BOA. A. DVNSAHK. DB. d.5, s. 55.

23 BOA. A. DVNSAHK. DB. d.1, s. 195.

24 BOA. A. DVN. ŞKT. d. 987, s. 12.

25 BOA. A. DVNSAHK. DB. d.2, s. 305.

26 BOA. A. DVNSAHK. DB. d.5, s. 43. 
bu işi özel bir teşkilât haline getirme eğilimi olarak sürüp gitmiştir. İslam tarihinde "yol kesen" anlamına gelen harabe, harami ve kuttau't-tarik tabirleri kullanılırken, Osmanlı Devleti'nde bu işi yapanlara şaki ve bunun çoğulu olarak eşkıya tabiri kullanılmıştır. ${ }^{27}$ Osmanlı'da XVI. yüzyılın ikinci yarısından itibaren iç güvenlik gün geçtikçe bozulmaya başlamıştır. Özellikle XVII. yüzyılda fetihlerin durma noktasına gelmesi, uzun süre devam eden savașlar, nüfus artışı, tîmâr sistemi için yeterli arazinin bulunamaması ve yüksek enflasyon devleti derinden sarsmıştır. ${ }^{28}$ Devlet, gücünü uzun süren savaşlara ayırdığından içte eşkıyalık ve soygunculuk artmış, sefere giderken kaçanlar ile asker olmamak amacı ile dağlara çıkanlar etraflarına topladıkları işsiz-güçsüz kimselerle asayişin bozulmasına sebep olmuşlardır. ${ }^{29}$ XVII. yüzyılda mevcut olan ve eşkıyalık hareketlerini tetikleyen sebeplerin ortadan kaldırılamamış olması XVIII. yüzyılda da bu hareketlerin sürmesine neden olmuştur. ${ }^{30}$

Bu dönemde gerek Diyarbekir Eyâleti'nde, gerekse Amid kazâsı'nda farklı türden eşkıyalık hareketleri olmuştur. Kayıtlara yansıdığı ölçüde bireysel yapılan eșkıyalık vakaları olabildiği gibi, bir çetenin veya aşiretin yaptı̆̆ı eylemlere de tesadüf edilmektedir. Özellikle ahkâm-ı şikâyet defterlerinde bu hadiseler ile ilgili çok sayıda şikâyet kaydı bulunmaktadır. ${ }^{31}$

Eşkıyalık yapan kimseler, kış aylarında barınacak yer ve yiyecek temin edemedikleri için yağma, talan, yol kesme vb. faaliyetler bu mevsimdeazalmaktaydı. Mesela Diyarbekir, Bağdat, Basra, Şehrizor Eyâletleri valileri ve kadılarına gönderilen 8 Nisan 1747 tarihli bir fermanda "mezâlim ve teâddîyatdan husus-ı eşkıya ve haramzadelerin öteden beri mevsim bahar hulûlü ile ağaçlar yapraklanıp eşkıya yaslanacak zamanlar geldikte başıboş levandât eşkıyasından muhafaza olunmak" şeklinde açıklandığı üzere eşkıyaların bahar aylarında ağaçların yapraklanması nedeniyle saklanacak yer temin edebildikleri ve anarşi olaylarının bu aylarda artış göstereceğinden, halkın can ve mal güvenliğine dikkat edilmesi istenilmektedir. ${ }^{32}$ Eşkıyalık olaylarının önlenmesi, eşkıya çetelerinin faaliyetlerinin azaltılması ve yakalanacak eşkıyanın haklarında gerekli muamelenin yapılması için 28 Mart 1703 tarihinde Diyarbekir mütesellimine gönderilen bir fermanda, Diyarbekir valisi Hasan Paşa'nın Bağdat'ta olması dolayısıyla çevredeki eşkıya ve haramzadelerden halkın korunması ve gerekentüm tedbirin alınması emredilmektedir. ${ }^{33}$

Amid kadısına Diyarbekir Eyâleti'ndeki ocaklık, hükümet sancak kadılarına ve

27 Müctebaİlgürel, “Osmanlılarda Eşkıyalık Hareketleri”, DİA, Türk Diyanet Vakfı Yayınları, İstanbul 1995, XI, s. 466-467; Karen Barkey, Eşkıyalar ve Devlet Osmanlı Tarzı Devlet Merkezileşmesi, Çev. Zeynep Altok, Tarih Vakfi Yurt Yayınları, İstanbul 2011, s. 181-194.

28 Bilgehan Pamuk, "XVII. Asır Başlarında Erzurum ve Havalisinde Eşkıyalık Hareketleri”, Osmanlıdan Günümüze Eşkııalık ve Terör, Ed. Osman Köse, Samsun İlkadım Belediyesi Kültür Yayınları, Samsun 2009, s. 49.

29 Musa Çadırcı “Tanzimatın İlanı Sırasında Anadolu’da İç Güvenlik”, TAD, 13(24), Ankara 1980, s. 45-46; Çağatay Uluçay, XVII. Asırda Saruhan’da Eşkıyalık ve Halk Hareketleri, Resimli Ay Matbaası, İstanbul 1944, s. 140.

30 Selim Özcan “XVIII. Yüzyılda Canik (Samsun) Sancağında Eşkıyalık Hareketleri”, Osmanlı’dan Günümüze Eşkıyalık ve Terör, Ed. Osman Köse, Samsun İlkadım Belediyesi Kültür Müdürlüğü Yayınları, Samsun 2009, s. 85.

31 BOA. A. DVNSAHK. DB. d. 1, 10; BOA. A. DVNSAHK. DB. d. 2, 284; BOA. A. DVNSAHK. DB. d. 3, 8; BOA. A. DVNSAHK. DB. d. 4, 9; BOA. A. DVNSAHK. DB. d. 5, s. 109.

32 DŞS. 313, 193.

33 Başbakanlık Osmanlı Arşivi, Divan-1 Hümayun Sicilleri, Mühimme Defterleri 114, s. 121. Bundan sonra BOA, A. DVN. MHM. 
ayan-ı vilayete gönderilen 8 Nisan 1721 tarihli başka bir fermanda, çevredeki eşkıya ve haramzadelere firsat verilmeyerek men ve def edilmeleri emredilmektedir. ${ }^{34}$ Yine 19 Kasım 1732 tarihinde Amid kadısına ve ayan-ı vilayete gönderilen başka bir fermanda "eşkıya ve haramzadelerin tecessüs ve tefahhusunda ihtimam ve dikkat hudud ve sınırınız dâhilinde her ne mahalde birden ve ikiden eşklya zuhur ider ise kat'a aman ve zaman verilmeyüb ahz ve ele getirilip müstahak oldukları ceza ve sezâları tertip etmeğle..."şeklinde eşkıyaların verecekleri her türlü zararın önlemesi ve yakalananların haklarından gelinip, hak ettikleri cezaların verilmesi istenilmiştir. ${ }^{35}$ Yine eşkıyalık hareketlerinin önlenmesi için 28 Temmuz 1775 tarihinde Diyarbekir, Sivas ve Musul valilerine gönderilen bir fermanda Sivas'tan Bağdat'a kadar yol üzerinde bulunan bütün kazâ ve nahiyelerde kapısız levent eşkıyasının hakkından gelinerek, asayişin temin edilmesi için her türlü tedbirin alınması emredilmektedir. ${ }^{36}$ Eşkıya çeteleri ve kapısız levent halkı ile mücadele için yöneticilere farklı tarihlerde fermanların gönderilmesi ve Diyarbekir'de görevli paşaların ${ }^{37}$ gayretleri sayesinde bölgedeki eşkıyalık vakaları dönem dönem azalma göstermiștir.

XVIII. yüzyılda bölgede yaşanan eşkıyalık olaylarının önemli bir kısmında Amid kırsalında yaşayan konar-göçer aşiret ve cemaatlerin adı geçmektedir. Bu dönem içerisinde eşkıyalık ile isimleri özdeșleşen özellikle üç aşiret ön plana çıkmaktadır. Bunlar Milli Aşireti, Koyunoğulları Aşireti ve Şeyh Hobak Cemaatidir. XVIII. yüzyılın hemen başlarında Milli Aşireti zorbalık ve zulümleri sebebiyle 1711 yılında devlet tarafından Rakka'ya sürülmüş olmasına rağmen $^{38}$ Diyarbekir Eyâleti'nde bulunan hükümet beylerine ve diğer sancakbeylerine gönderilen 10 Aralık 1722 tarihli bir fermana göre Milli Aşireti'nin çevrede yaptığı eşkıyalık olaylarının halkı zor duruma düşürdüğünden bu olayların derhal sona erdirilerek gerekli görülenlere hak ettikleri cezaların verilmesi emredilmektedir. ${ }^{39}$ Milli Aşireti'nin eşkıyalığg ile ilgili 24 Temmuz 1724 tarihli başka bir olayda Amid kazâsı halkından Seyyid Ahmet adlı şahıs mahkemeye gelerek, Şarki Amid Nahiyesi'ne bağlı Kadıkendi ve Kasımi karyeleri civarında gece ile geçerken bir grup eşkıya tarafından yolunun kesilerek öldürme kastıyla başına vurularak yaralandığını, katır ve bazı eşyalarının da gasp edildiğini bildirmiştir. Bu olayı gerçekleştirenlerin Kadıkendi karyesi ahalisinden Arakil adlı zimmî ve arkadaşları olduğunu zannettiğini ancak yapılan tetkik sonucunda Arakil'in suçsuz olduğu, bu olayı "eşkıyalık ve zulüm ile meşhur"Milli Aşireti adamlarının gerçekleştirdiği tespit edilmiştir. ${ }^{40}$ Yine Diyarbekir valisine gönderilen 8 Haziran 1758 tarihli başka bir fermanda Milli Așireti iskanbașısı Timur'un Diyarbekir kırsalında Türkmen tâifesine sürekli taarruzda ve şekavette bulunduğu ve Türkmenlerin mal ve eşyalarını soyarak, zulüm ve zorbalıkta bulunduğundan

34 BOA, A. DVN. MHM. d. 130, s. 150.

35 DŞS. 313, s. 49.

36 BOA, Cevdet Zabtiye 1874, s. 1.

37 Diyarbekir valisi Çeteci Abdullah Paşa eşkıya çetelerini yakalayarak haklarından gelmesi ile meşhurdur. Kendisine bu lakap eşkıya çeteleri ile olan başarılı mücadelesinden dolayı verilmiş olup, gösterdiği başarılardan dolayı 1740-1759 yılları arasında beş kez Diyarbekir valiliği görevine atanmıştır. Abdulgani Fahri Bulduk, Diyarbakır Valileri, Medrese Yayınları, Ankara 2007, s. 107-110.

38 Diyarbekir bölgesinde bulunan konar-göçer Milli Aşireti şekavet üzere olduğundan, Rakka’ya sürülmesi kararlaştırılmış ve 1711 yılında buraya iskân edilmişlerdir. Yusuf Halaçoğlu, XVIII. Yüzyılda Osmanlı İmparatorluğu'nun İskân Siyaseti ve Aşiretlerin Yerleştirilmesi, TTK Yayınları, Ankara 1997, s. 136.

39 BOA, A. DVN. MHM. d. 131, s. 20.

40 DŞS. ror, s. 8. 
bu duruma kesinlikle müsaade edilmemesi istenmektedir. ${ }^{41}$ Şark-i Amid Nahiyesi'ne bağlı Davudi, Böhtükan, Behramki karyeleri halkı 9 Nisan 1767 tarihinde Dîvân-ı Hümâyûn'a müracaat ederek, Milli Aşireti eşkıyasından Teymürci ve Habur adlı eşkıyanın başka eşkıya gruplarını da yanlarına alarak karyelerini bastıkları, üç katırları ile 6000 kuruş değerinde mal ve eşyalarını gasp ederek kaçtıklarından adaletin sağlanması için Amid kadısına ve Diyarbekir valisine emr-i şerif gönderilmiștir. ${ }^{42}$ Yukarıda verilen olaylardan anlaşılacağı üzere incelenilen dönemde Milli Aşireti'nin eşkıyalık olayları sebebiyle devlet tarafından 1711 yılında Rakka'ya sürülmesine rağmen geride kalan veya zorunlu iskân emrine uymayan bu aşiret mensuplarının Amid kazâsı çevresinde zorbalık ve eşkıyalık hareketlerine devam ettikleri görülmektedir.

Amid çevresindeki eşkıyalık olaylarında isimleri anılan konar-göçerler içerisinde Koyunoğulları Aşireti ve Şeyh Hobak Cemaati de bulunmaktadır. XVIII. yüzyılın ilk yarısında bölgede eşkıyalık olayları görülen bu konar-göçerlerin şekavetleri ile ilgili Diyarbekir valisine gönderilen 3 Temmuz 1714 tarihli bir fermanda Koyunoğulları Aşireti eşkıyasının Divriği ve Diyarbekir arasındaki çok geniş bir alanda şekavet üzere olduğundan, başta Çemişgezek Kazâsı olmak üzere Diyarbekir Eyâleti'nin birçok kazâsında eşkıyalık faaliyetinde bulunduklarından, hak ettikleri cezaların verilmesi istenmektedir. ${ }^{43}$ Amid kazâsı halkından Haçok adlı zimmî 20 Eylül 1742'de dîvân-ı hümâyûn'a müracaat ederek, zulüm ve zorbalık ile meşhur Sefer adlı şahsın, Şeyh Hobak Cemaati'nden bazı adamlar ile birleşerek evini bastıkları ve kendisini öldürmek amacıyla saldırdıkları mal ve birçok eşyasını gasp ettiklerinden şikâyetçi olmuştur. ${ }^{44}$

XVIII. yüzyılda Amid çevresinde yaşayan konar-göçer aşiret ve cemaatlerin dönemin siyasî durumu sebebiyle isyan ve ayaklanmalar başlattıkları ayrıca bu karmaşa esnasında Amid karyelerini yağma ederek, bölge halkına taciz ve taarruzda bulundukları da görülmektedir. Diyarbekir valisine gönderilen 4 Mayıs 1733 tarihli bir fermanda, konargöçer Kürt aşiretlerinin İran harpleri sebebiyle Amid karyelerinde yağma ve talan yapmaya başladıkları, halkın mal ve eşyalarını gasp etmeleri sebebiyle karye halkının "perakende ve perişan" durumda olduğu, hatta bu aşiretlerin Amid Kalesi dışına kadar gelip Amid halkına baskı yapmaya başladıklarından, bu duruma derhal son verilerek asayiş ve düzenin tesis edilmesi emredilmiştir. ${ }^{45}$

İncelenilen dönem içerisinde bölgede yaşanan eşkıyalık ve zorbalık olayları sadece konar-göçerlerin yaptığı eylemlerden ibaret değildir. Bu dönemde bir veya birden fazla kişinin gerçekleştirdiği olaylar veya kendine çıkar sağlamak isteyen kimselerin eşkıya çeteleri ile işbirliği içerisine girerek yapmış oldukları eşkıyalık olayları da dikkat çekmektedir. Bu olaylar sebebiyle bölgedeki birçok insanın huzur ve güveninin sarsıldığı görülmektedir. Mesela Amid kazâsı'na tabi Ali Pınarı karyesi ahalisi dîvâna müracaat ederek, karyelerinde sakin Timur Beşe'nin haksız iddia ve bahaneler öne sürerek halka zulüm ve zorbalıkyaptığınısöylemişlerdir. Timur Beşe'nin zorbalığının engellenmesi için 6 Mart 1725 tarihinde Diyarbekir valisine

41 BOA, A. DVN. MHM. d. 160, s. 215.

42 BOA. A. DVNSAHK. DB. d. 3, s. 164.

43 BOA, A. DVN. MHM. d. 122, s. 87.

44 BOA. A. DVNSAHK. DB. d. 1, s. 7.

45 BOA, A. DVN. MHM. d. 139, s. 186. 
ve Amid kadısına hüküm gönderilmiştir. ${ }^{46}$ Amid sakini Hacı Mehmet ve oğlunun kimseyle düşmanlıkları yok iken, 15 Haziran 1750 tarihinde Amid ahalisinden Osman yanına eşkıyadan birkaç kişiyi alarak Hacı Mehmet'in evini basmış, evdeki bazı eşyalara el koyup, Hacı Mehmet'in hanımı Ayşe Hatun'u da kendisine zorla nikâh etmiştir. ${ }^{47}$ Amid halkından İbrahim 31 Ekim 1750'de dîvân-ı hümâyûna müracaat ederek, Amid halkından bazılarının eşkıya çeteleri ile bir olarak evini bastıkları, mal ve eşyalarını gasp edip iki adamını öldürdüklerinden şikâyet etmiştir. ${ }^{48}$ Amid kazâsı'na bağlı Ahmetli Karyesi ahalisi 23 Mart 1775'te dîvân-ı hümâyûn'a şikâyette bulunarak, Amid kazâsı halkından Seyyid Mehmet Efendi'nin eşkıya ile bir olarak karyelerini bastığını, 800 kuruş paraları ile çeşitli mal ve eşyalarını gasp ederek zorbalık ettiğinden adaletin sağlanarak gasp edilen para ve mallarının geri alınmasını istemişlerdir. ${ }^{49}$

Yönetici sınıfa mensup kimseler de halka zulüm ve zorbalık yaparak şekavete bais olabilmekteydiler. Mesela Diyarbekir valisine gönderilen 4 Mayıs 1761 tarihli bir fermanda, Çarsancak voyvodası olan Karaçorluoğlu Mustafa eşkıyalık yapmaya başlayarak çevreye zulüm ve şekavet ettiğinden, yakalanarak gerekli görülen cezanın verilmesi istenmiştir. Diyarbekir valisi Feyzullah Paşa marifetiyle yakalanan Karaçorlu Mustafa Amid Kalesi'ne hapsedilerek, tüm mal varlığına devlet tarafından el konulmuştur. ${ }^{50}$ Yine 2 Mayıs 1792 tarihli başka bir olayda Diyarbekir Şafii müftüsü Mahmut yanına ahaliden on beş kişiyi alarak, Diyarbekir voyvodası ve mütesellimi olan Şeyhzade İbrahim'i dîvân-ı hümâyûn'a şikâyet etmiştir. Diyarbekir voyvodası Şeyhzade İbrahim, Diyarbekir Eyâleti sancakbeylerinden Abdullah Bey ve Mustafa Bey ile birlikte Amid kazâsı Hanefi müftüsünün Keraz adlı karyesini basıp, karye ahalisinden on bir kişiyi haksız şekilde katledip, üç yüz kese miktarı akçeleri ile iki yüz koyunlarını gasp ederek zulüm ve katliam yapmışlardır. ${ }^{1}$

Amid kazâsı'nda meydana gelen eşkıyalık olaylarına ekonominin ve toprak yönetiminin giderek bozulması, çeşitli sosyal sorunlar, harplerin kaybedilmesi, devletin güç ve otoritesinin giderek zayıflaması gibi birçok sebep zemin oluşturmuştur. Devlet, bölgede yaşanan eşkıyalık ve zorbalık olaylarını önlemek için azami gayreti sarf etmesine ve eşkıyanın yok edilmesi için bölge idarecilerine sürekli emir ve fermanlar göndermesine rağmen bu olaylar sürüp gitmiștir. Konar-göçerlerin veya eşkıya çetelerinin yaptıkları eylemlerin azaldığı dönemlerde bireysel eşkıyalık olayları ön plan çıkmıştır. Arşiv belgelerinden Amid halkının can, mal ve namus güvenliğinin sağlanması ve adaletin tesis edilmesi için divana ve mahkemeye şikâyetlerini bildirerek bu olaylara çözüm arayışında bulunduğu devletin de asayişi sağlamak adına gayret ettiği belgelereyansımaktadır.

\section{3-Sebepsiz Müdahale}

Gündelik hayatta karşılaşılan sorunlardan bir diğeri de sebepsiz müdahalelerdi. Bu duruma maruz kalan kişiler sorunlarına çözüm bulabilmek için Dîvân-ı Hümâyûn'a başvuruyorlardı. Göreve yapılan müdahaleler içerisinde en çok şikâyet edilen husus, vakıf

\footnotetext{
46 BOA. DVNS. ŞKT. d. 105, s. 59.

47 BOA. A. DVNSAHK. DB. d.1, s. 163.

48 BOA. A. DVNSAHK. DB. d.1, s. 196.

49 BOA. A. DVNSAHK. DB. d.3, s. 240.

50 BOA, Cevdet Maliye. 27989, s. 1-3.

51 BOA, A. DVN. MHM. d. 186, s. 91; DŞS. 626, s. 13.
} 
görevlilerine yapılan taciz ve müdahalelerdir.Bu müdahaleler bazen vakıf mütevellisi tarafından olabileceği gibi bazen de dışarıdan kimselerden kaynaklanabilmekteydi. Mesela Amid halkından Mehmet Emin divana müracaat ederek, babasının Amid'de bulunan Kastal Mescidi'nde günlük dört akçe ile imamlık ve bir akçe ile müezzinlik yaptığını söylemiștir. Ancak Amid halkından Mahmut babasının görevine çeşitli bahaneler ile müdahale ettiğini ve bu durumu Amid kadısı Yusuf'a iletmelerine rağmen çözüm bulunamadığından Mahmut'un müdahalesinin engellenmesini talep etmişlerdir. Meselenin halledilmesi için 25 Ağustos 1720 tarihinde Diyarbekir valisine hüküm gönderilmiştir. ${ }^{52}$ Camii-i Kebir'in günlük 15 akçe vazife ile sermahfil ve müezzini olan Seyyid Hacı Abdulbaki de divana müracaat ederek, vakıf mütevellisinin görevine müdahale ettiği ve görevini elinden almak istediğinden şikâyet etmiştir. ${ }^{53}$ Amid'de bulunan Ali Paşa Camiisi'nde muallim-i sıbyanlık görevindeki Abdurrahman şikâyette bulunarak elinde berat-ı şerif olmasına rağmen vakıf mütevellisinin ve ferraşının görevine haksız șekilde müdahale edip rahatsız verdiklerinden müdahalenin men edilmesi için dîvân-ı hümâyûna müracaat etmiştir. ${ }^{54}$

Göreve yapılan haksız müdahaleler sadece vakıflar ile sınırlı değildir. Amid halkından Abdullah adlı şahıs, Dağ Kapısı haricinde sığırtmaçlık görevini yaparken, kazâ ahalisinden bazı kimselerin "biz senin sığırtmaçlığın istemeziz" diyerek görevine müdahale ve tacizde bulunduklarından müdahalenin engellenmesi için Diyarbekir valisine ve Amid monlasına emr-i șerif yazılmıștır. ${ }^{55}$ Yine Çulcu esnafından Yusuf dîvân-ı hümâyûna müracaat ederek, elinde görev beratı olmasına rağmen, bazı kimselerin haksız yere işlerine karışarak müdahale ettiklerinden şikâyet etmiştir. ${ }^{56}$

Sebepsiz müdahalelerden bir diğeri de arazi ve gayrimenkullere yapılan tacizlerdir ki genellikle kişilerin mutasarrıf oldukları bağ, bahçe, arazi, ev, dükkân gibi mülkleri kapsamaktadır. Kişilerin ellerinde beratları veya tapuları olmasına rağmen, dışarıdan bazı kimselerin çeşitli bahaneler öne sürerek taciz ve müdahalelerde bulunmaları bu sorunların ana sebebini oluşturmaktadır.

Garb-i Amid Nahiyesi'ne tabi Ramori Karyesin'de 1700 akçelik tîmâra sahip Resul divana şikâyette bulunarak, Diyarbekir voyvodası Ahmet'in haksız şekilde tîmârına müdahalede bulunduğunu söylemiștir. Diyarbekirvoyvodası ve mütesellimi Ahmet'in haksız müdahalesinin engellenmesi için 26 Mayıs 1703'de tarihinde Amid kadısına hüküm gönderilmiștir. ${ }^{57}$ Garb-i Amid Nahiyesi'nde 21.411 akçe zeâmete müşterek sahip olan Mehmet Emin, Ali ve Mustafa adlı zaimler de 29 Haziran 1747 tarihinde dîvân-ı hümâyûna müracaat edip, Mustafa adlı bir şahsın gelerek "sizin zeâmetinizi havass-ı hümâyûna taksim ederim deyü hilâf-ı defter-i hakâni" müdahale edip mahsul ve vergilerine el koymak istemesinden şikâyet etmişlerdir. Meselenin halledilmesi için defterhanedeki ilgili kayıtlar incelenerek haksızlık giderilmiştir. ${ }^{58}$ Yine Amid halkından Hacı Ali Ağa, Rum Kapısı haricinde sahibi olduğu arazisine Ahmet adlı şahıs "sizin

52 BOA. A. DVNS. ŞKT. d. 86, s. 135.

53 BOA. A. DVNSAHK. DB. d. 2, s. 115

54 BOA. A. DVNSAHK. DB. d. 3, s. 44.

55 BOA. A. DVNSAHK. DB. d. 1,s. 7.

56 BOA. A. DVNSAHK. DB. d. 2, s. 39.

57 BOA. A. DVNS. ŞKT. d. 39, s. 174.

58 BOA. A. DVNSAHK. DB. d. 1, s. 121. 
mülkünüz Ahmet Ağanın mektebi vakfının akarı imiş sizden alırım" diyerek haksız gerekçeler ile müdahale ettiğinden, 15 Ekim 1785 tarihinde divana müracaat ederek müdahalenin engellenmesi istemiștir. ${ }^{59}$

Çeşitli bahaneler öne sürerek insanlara huzursuzluk veren kimselerin yaptığı eylemlerden bir diğeri de ev, dükkân gibi yerlerin mülkiyet hakkına müdahaledir. Mesela Seyyid Ömer Efendi, Rum Kapısı haricinde bulunan ve on altı seneden beri mülkiyetinde olan dükkânına bazı kimselerin sebepsiz müdahalelerinin olduğunu bildirmiștir. ${ }^{60}$ Amid halkından Azizzade Şeyh Abdullah divana müracaat ederek Rum Kapısı'ndaki dükkânına kazâ halkından bazı kimselerin ve Diyarbekir voyvodası tarafından usulsüz şekilde müdahale ve tacizlerinin olduğunu söylemiştir. Dükkânına yapılan müdahale ve tacizin men edilmesi için 19 Eylül 1734 tarihinde Diyarbekir valisine ve Amid kadısına hüküm gönderilmiștir. ${ }^{61}$ Yine kazâ halkından Fatma Hatun'un kendisine ait olan evi, babası Fatma Hatun'a haber vermeden 30 Eylül 1743 tarihinde başka birine satmıştır. Evi alan şahıs vefat ettiğinden varisleri olan çocukları ev üzerinde hak iddia etmişlerdir. Ancak yapılan tetkik neticesinde evi Fatma Hatun'un kendi izni ile satmadığı tespit edildiğinden müdahalenin men edilmesine karar verilmiştir. ${ }^{62}$

\section{4-Alacak-Verecek Meseleleri}

Gündelik hayat içerisinde sıkça rastlanan şikâyetlerden bir diğeri de borç, alacakverecek davalarıdır. Amid kazâsı'nda gündelik hayatta meydana gelen ve șer'iyye sicillerine yansıyan on bir, ahkâm-ı şikâyet defterlerine yansıyan doksan altı dava, şikâyet ve atik şikâyet defterlerine yansıyan beş kayıt tespit edilebilmiştir. Bu davalar genellikle kişiler arasındaki küçük miktarlardaki borçlar ile ilgili olup toplum içindeki geniş kitleleri ilgilendiren borç davası kaydı yoktur. Bu davalarda kişilerin verdikleri borçları istediklerinde borç inkârları ${ }^{63}$ veya borcun ödendiği halde, alacaklının tekrar tekrar para talep etmesi ${ }^{64}$ gibi durumlar oluşturmaktadır. Yine bu davalar ışığında kazâdaki Müslüman ve gayrimüslimlerin birbirilerinden borç alıp verebildikleri de tespit edilmiştir.

Davalarda kişilerin cihet-i karz ${ }^{65}$, karz-1 șer ${ }^{66}$ veya ba-temessük ${ }^{67}$ ile birbirlerine verdikleri nakit paraları almak istediklerinde yaşadıkları sorunlar ön plana çıkmaktadır. ${ }^{68}$ Borç inkârı ve verdiği parayı alamayan şahısların şikâyetlerinden bazıları şu şekildedir. Amid halkından Ahmet Çelebi adlı şahıs divana müracaat ederek, yine Amid halkından Ömer adlı şahıs zimmetinde 350 kuruş alacak parasının olduğunu söylemiştir. Bu parayı Ömer'den almak

59 BOA. A. DVNSAHK. DB. d. 4, s. 125.

60 BOA. A. DVNSAHK. DB. d. 2, s. 62.

61 BOA. A. DVN. ŞKT. d. 1003, s. 155.

62 BOA. A. DVNSAHK. DB. d. 1, s. 26.

63 BOA. A. DVNSAHK. DB. d. 3, s. 29.

64 DŞS. 626, s. 57.

65 DŞS. 592, s. 2. Karz: ödünç verme, ödünç alma, ödünç verilen veya alınan şey, borç. Devellioğlu, OsmanlıcaTürkçe Ansiklopedik Lûgat, s. 565.

66 BOA. A. DNVSAHK. DB. d. 2, s. 95.

67 BOA. A. DVNSAHK. DB. d. 2, s. 29; Temessük: Borç Senedi, Makbuz; Devellioğlu, Osmanlıca-Türkçe Ansiklopedik Lûgat, s. 1251.

68 BOA. A. DVNS. ŞKT. d. 74, s. 132; BOA. DVN. ŞKT. d. 987, s. 3. 
için defalarca talepte bulunmasına rağmen alamadığından paranın alınması için 18 Temmuz 1700 tarihinde Dîvân-ı Hümâyûn'dan hüküm gönderilmiştir. ${ }^{69}$ Amid halkından Mehmet divana başvurarak, Halil zimmetinde makbuz ile sabit olan 480 kuruşu olduğunu ve bu parayı Halil'den talep ettiğinde Halil'in çeşitli bahaneler öne sürerek ödemeye yanaşmadığından paranın Mehmet'e alınması için 8 Mart 1713'de Amid monlasına ve Diyarbekir mütesellimine hüküm gönderilmiştir. ${ }^{70}$ Diyarbekir valisine gönderilen 2 Ağustos 1713 tarihli başka hükümde Diyarbekir'de görev yapan ağalardan birinin Amid halkından Hacı Hasan'a 1000 kuruş borcu olduğu, Hacı Hasan'ın parayı almak istediğinde çeşitli bahane ve zorbalık ile karşılaştığından, paranın ağadan tahsil edilerek Hacı Hasan'aödenmesiistenmektedir. ${ }^{71}$ Molla Tatar'ın yine kazâ halkından Hasan Ağa zimmetinde alacağı olduğu, Molla Tatar'ın parasını almak istediğinde Hasan Ağa'nın çeşitli bahaneler öne sürerek borcu ödemeye yanaşmadığından 19 Ekim 1781 tarihinde divana müracaat ederek parasının tahsil edilmesini istemiștir. ${ }^{72} 2$ Ağustos 1789 tarihli bașka bir olayda ulemadan Abbas Dîvân-ı Hümâyûn'a müracaat ederek, Hacı Salim zimmetinde 4421 kuruş alacağı olmasına rağmen bir türlü alamadığını parayı Hacı Salim'den istediğinde her defasında muhalefet ve bahaneler ile karşılaştığından paranın kendisine tahsil edilmesini istemiştir. Meselenin halledilmesi ve borç paranın Abbas'a alınması için Amid monlasına ve Diyarbekir mütesellimine hüküm gönderilmiștir. ${ }^{73}$

Borç olarak alınan paranın tamamen ödenmesine rağmen, alacaklıların tekrar para talep etmesi de sık rastlanan durumlardandır. Mesela Dizdar İsmail Ağa oğlu Feyzullah 5 Haziran 1792'de mahkemeye başvurarak, “Mehmet Emin Ağa zimmetinde 750 kuruş alacak hakkım var" diyerek dava etmiștir. Mehmet Emin Ağa borcun 329 kuruşunu verdiğini kalan 421 kuruşu İsmail Ağa ile gönderdiğini ve borcunu tamamen ödediğini beyan etmiştir. Mahkeme mahalledeki Müslümanlara durumu sorduğunda Mehmet Emin Ağa'nın parayı ödediği ve hiç borcu olmadığını beyan etmişlerdir. ${ }^{74}$ Yine Hacı İzzeddin Mahallesi halkından Yusuf oğlu Mahmut Halil 27 Mart 1724 tarihinde mahkemeye gelerek, Hasan oğlu Ahmet zimmetinde 120 kuruş alacağı olduğunu ve parasını alamadığını beyan etmiștir. Ahmet Hasan oğlu Ahmet ise borcunu ödediğini sadece on beş kuruş borcu kaldığını bu parayı vermesi halinde hiç borcu kalmayacağını söylemişti. ${ }^{75}$

Borç davalarında dikkat çeken başka bir husus borç alan şahısların borçlarını ödememek için şehrin önde gelen kimselerine güvenerek hareket etmeleridir. Mesela İsmail, Hüsameddin Beşe zimmetinde bulunan 655 kuruşunu almak istediğinde Hüsameddin Beşe'nin parayı ödemediğini hatta şehrin önde gelen kimselerine istinaden borcunu ödemediğinden paranın Hüsameddin Beşe'den tahsil edilmesi için hüküm yazılmıştı. ${ }^{76}$

69 BOA, A. DVNS. ŞKT. d. 32, s. 174.

70 BOA. A. DVNS. ŞKT. d. 62, s. 202.

71 BOA, A. DVN. MHM. d. 121, s. 57.

72 BOA. A. DVNSAHK. DB. d. 4, s. 33.

73 BOA, A. DVN. MHM. d. 191, s. 21.

74 DŞS. 626, s. 57.

75 DŞS. 352, s. 7.

76 BOA. A. DVNSAHK. DB. d. 3, s. 194. 
Alacak-verecek ilişkilerinde borç sadece nakit para ile sınırlı olmayıp hayvan ve eşya gibi çeşitli mallardan da olabilmektedir. Mesela Barsum adlı gayrımüslim divana şikâyette bulunarak, babası Serkis'in Amid halkından Samak adlı gayrımüslime bir miktar altın, bir gümüş tas, bir yakut yüzük, iki katır ve bir at verdiğini söylemiştir. Ancak Samak'ın ölmesi üzerine mirasını kabz eden kimselerin bu borçları ödemeye yanaşmadığından Samak'ın mirası dâhilinde olan eşya ve hayvanların Barsum'a iade edilmesi için 16 Ocak 1715 tarihinde Amid kazâsı'na hüküm gönderilmiştir. ${ }^{77}$ Hacı Macit 3 Haziran 1743 tarihinde divana müracaat ederek, Diyarbekir voyvodası Mustafa zimmetinde 7000 kuruş parası ve dokuz atı bulunduğu ancak Diyarbekir voyvodası Mustafa'nın vefat etmesi üzerine borcun terekesinden ödenmesini istediğinde varislerin borcu ödemek istemediklerinden, 7000 kuruş parası ve dokuz atının kendisine tahsil edilmesini istemiști. ${ }^{78}$

Alacak-verecek meselelerinin çözülmesinde uygulanan yöntemlerden bir diğeri de borcun ölen kimsenin terekesinden tahsil edilmesidir. Şeyh Matar Mahallesi'nden Hindi oğlu Çerkes 17 Temmuz 1723 tarihinde mahkemeye gelerek, Kiki Aşireti'nden Ahmet oğlu İbrahim'in zimmetinde alacağı olduğu halde vefat ettiğinden Ahmet oğlu İbrahim'in terekesinden alacağının tahsil edilmesini istemiştir. Müslümanlardan Hacı Yusuf oğlu Sarraf Mahmut Çelebi ve Haydar oğlu Karakeçili Hüseyin'in ifadesi üzerine borcun Ahmet oğlu İbrahim'in terekesinden ödenmesine karar verilmiştir. ${ }^{79}$ Ali Paşa Mahallesi halkından Hacı Ali oğlu Seyyid Ebubekir Ağa adlı şahıs 19 Mart 1733 tarihinde mahkemeye gelerek, Mustafa oğlu Uzun Mehmet Ağa'nın kendisine cihet-i deyn-i şerden ${ }^{80}$ borcu olduğu halde vefat ettiğinden alacağının Uzun Mehmet Ağa'nın terekesinden tahsil edilmesini istemiştir. Müslüman ahaliden Abdullah oğlu Kasım Ağa ve Emir-i Hac oğlu İbrahim Ağa adlı kimselerin şahadetleri ile borç Uzun Mehmet Ağa'nın terekesinden tahsil edilmiștir. ${ }^{81}$

Amid kazâsı'nda yaşanan alacak-verecek olaylarının büyük bir kısmında sorunun borç inkârından ve borcun ödenmemesinden kaynaklandığı anlaşılmaktadır. Borç para veren kişilerin alacaklarını tahsil etmek istediklerinde önce borçludan borcunu istemekte parayı tahsil edemediği durumlarda ise son çare olarak hukuki yollara başvurdukları görülmektedir. Devlet kişiler arasındaki alacak-verecek anlaşmazlıklarının çözümünde Amid kadısı, voyvodası, mütesellimi ve valisine görev vermektedir. Borç para veren şahısların mağdur edilmemesi ve paralarının borçludan tahsil edilebilmesi için gerektiğinde borçlu olarak ölen kimsenin mirasından da borcun tahsil edildiği belgelerden tespit edilmiştir.

77 BOA. A. DVNS. ŞKT. d. 67, s. 127.

78 BOA. A. DVNSAHK. DB. d. 1, s. 29.

79 "müteveffâ-i mezbûr zimmetinde hayatında yedimden iştira ve kabz eylediği bir çift cevahir küpe bahasından yüz seksen guruş hakkım olup hatta müteveffâ-i mezbû̉r hayatında lede'ş-şühûdikrâr ve işhâd edip meblağ-1 mezbûrukable'l- edâ fevt olmağın meblağ-1 mezbûru terekesinden talep ederim suâl olunsun...”’DŞS. 313, s. 69.

80 Deyn Sözcüğü mastar olarak "ödünç almak, ödünç vermek, emir ve itaat altına almak, ceza veya mükâfatla mukabelede bulunmak", isim olarak "ödünç satılan malın bedeli (semen) ve hazırda bulunmayan şey " manalarına gelir. Terim olarak ise "kişinin zimmetinde sabit olan borçları" ifade eder. Mehmet Akif Aydın, "Deyn", DİA, Türk Diyanet Vakfı Yayınları, İstanbul 1995, IX, s. 266.

81 "müteveffâ Uzun Mehmet Ağa zimmetinde yüz otuz guruş hakkım olub meblağ-1 mezbûrdan bir defa otuz guruş ve bir defa dahi yirmi beş guruş ki cem'an elli beş guruşumüteveffâ-yımezbûrun hayatında yedinden ahz ve kabz edip zimmetinde baki kalan yetmiş beş guruş hakkımı alâruûsi'l-eşhâdikrâr ve eşhâd dahi itmiş iken kable'l-ifa mezbûr Uzun Mehmet Ağa fevt olmağla terekesinden vasiyy-i mezbûrdan talep ederim suâl olunsun...” DŞS. 310, s. 39 . 


\section{5- Miras Taksimi ve Yașanan Anlașmazlıklar}

Osmanlı Devleti'nde vefat eden kişinin mirasçlarının istekleri veya devletin mirasçı olması durumunda, kadılık kurumu vefat eden kişinin mal ve nakit varlığını, alacaklarını tespit eder, değerlendirir, borçlarını öder, korumaya alır ve tereke defterine muhasebe kayıt düzenine göre kaydını yapardı. Bu kayıt işlemi yapılırken, bir yanda mal ve nakit varlığının tutar olarak değerine yer verilir, bir yandan da bu varlıkların borçlara, mirasçlara, devlete, kadılık işlemleri ücretlerine düşen kısımları kayıt altına alınırdı. Vefat eden kişinin varsa ticarethanesindeki varlıklarının ve borçlarının tümü bu hesaplamalarda göz önünde tutulurdu. ${ }^{82}$ Şayet vefat eden kimsenin herhangi bir varisi yoksa terekesi beytü'l-mal'a yani devlet hazinesine intikal ederdi. ${ }^{83}$

Miras taksimi sırasında taksimatı yapan kimseye "bölüştüren, taksim eden" anlamına gelen kassâm denilmektedir. Kassâmların miras taksimatını yaparken dellal, kâtip, hademe vb. gibi birtakım yardımcıları bulunmaktadır. Miras taksimatından önce ise resm-i kısmet, dellaliye, hamaliye, hüdamiye, ihzariye, teçhiz ve tekfin, katibiye, vb. harçlar kassâm tarafından ölen kimsenin terekesinden düşülmektedir. Terekelerden alınacak harçlar kanunnamelerde de ayrıntılı şekilde belirtilmektedir. ${ }^{84}$

Amid kazâsı'nda vefat eden kimselerin terekelerinden de harçlar düşüldükten sonra varislerine dağıtılmaktaydı. Mesela Sarraf İskender Mahallesi halkından iken 19 Mayıs 1739 tarihinde vefat eden Mustafa kızı Hatice Hatun'un 169 kuruşluk terekesi, kocası Sadık Beșe ile kızı Refiye ve annesi Ayșe Hanım'a intikal etmiştir. Tereke taksimatından önce kalemiye, ihzariye ve hüdamiye masrafı olarak bir kuruş, dellaliye, katibiye ve hamaliye masrafı olarak iki kuruş, resm-i kısmet dört kuruş olmak üzere toplam yedi kuruş harç alınmıș, geriye kalan 162 kuruş varisleri arasında taksim edilmiştir. ${ }^{85}$ Amid'in iç kalesinde 15 Şubat 1759'da vefat eden Ahmet Çavuş'un 2527 akçelik terekesi hanımı Ayşe Hatun'a oğlu Sadullah'a ve annesi Sariye Hanım'a intikal etmiştir. Bu terekenin taksimatından öncede teçhiz ve tekfin ücreti olarak 480 akçe, hamaliye ve katibiye ücreti yirmi dört akçe, kalemiye, hüddamiye, ihzariye ücreti on sekiz akçe, kaydiye on akçe ve resm-i kısmet altmış iki akçe olmak üzere toplam 594 akçe terekeden düşülerek varislere taksim edilmiștir. ${ }^{86}$

Terekelerin taksimatında her varis hissesine düşen miktarı almakta ve bu miktar defterlere kayıt edilmektedir. Ancak terekenin taksimi ve hisselerin paylaşılması yeni sorunları da beraberinde getirmektedir. Amid kazâsı'nda miras taksimi ve hisselerin paylaşılması esnasında veya taksimattan sonra yaşanan sıkıntılara dair çok sayıda şikâyet bulunmaktadır. Bu şikâyetler genel itibariyle, kişilere ailelerinden düşen mal ve mülke başkaları tarafından el konulması, mirasta hakkı olan şahısların hisselerinin tam olarak verilmeyişi veya kişilerin hisselerine düşen miktara kanaat etmeyerek fazladan hisse talep etmelerinden kaynaklanmaktadır. Ölen kimselerin mirasından kişilerin hissesine düşen

\footnotetext{
82 Fatih Coşkun Ertaş, Bülent Şişman, “ XVI. ve XVII. Yüzyıllarda Osmanlı’da Tereke Uygulaması ve MuhasebesiSosyo-Ekonomik Yapıya ve Miras Hukukuna Etkileri”, MUFITAD, Sayı: 4 İstanbul 2013, s. 199.

83 DŞS. 349, s. 13; DŞS. 327, s. 114; DŞS. 364, s. 95; DŞS. 315, s. 36; DŞS. 359, s. 56.

84 Sait Öztürk, “Kassâm”, DİA, Türk Diyanet Vakfı Yayınları, İstanbul 1995, XXIV, s. 579.

85 DŞS. 363, s. 15.

86 DŞS. 599 , s. 8.
} 
para, eşya veya gayrımenkullere dışarıdan yapılan müdahaleler çeşitli sorunlara sebep olmaktadır. Mesela Amid halkından Refika Hanım'ın vefatı üzerine kendisinden kalan miras İstanbul'da bulunan varisi Mehmet'e intikal etmiştir. Ancak Mehmet mirası almak istediğinde Amid halkından Mehmet Emin adlı şahıs hiçbir gerekçe göstermeden mirasa el koymuştur. Mehmet haksızlığın giderilmesi ve miras mallarının kendisine geri alınması için 23 Aralık 1757 tarihinde dîvân-ı hümâyûn'a başvurmuştur. ${ }^{87}$ Amid halkından Karakız Mehmet Ağa'nın vefatı sebebiyle mirası Ahmet adlı şahsa intikal etmiştir. Ahmet kendisine intikal mirasa Amid halkından Abdurrahman'ın haksız şekilde el koyduğunu söyleyerek 24 Ocak 1764 tarihinde divana şikâyette bulunmuştur. Ahmet zapt edilen miras mallarını kendisine almak istediğinde Abdurrahman'ın türlü bahaneler öne sürerek miras mallarını vermeye yanaşmadığından haksızlığın giderilmesi için Diyarbekir valisine ve Amid kadısına hüküm gönderilmiştir. ${ }^{88}$ Yine Amid halkından Refiye Hanım 22 Temmuz 1780'de divana müracaat ederek, babasının vefatı sebebiyle kendisine intikal eden bir dükkânın olduğu ve kendisinden başka varisin olmamasına rağmen, Amid halkından bazı kimselerin "senin babandan biz dükkânı almış idik" diyerek haksız iddialarda bulundukları ve kendisine intikal eden dükkânı zapt ettiklerini söylemiștir. Refiye Hanım meselenin halledilmesi ve dükkânın kendisine alınmasını talep etmiştir. ${ }^{89}$

Kişilerin hisselerine düșen mal, eşya veya paraya kanaat etmemesi de gündelik hayatta sorunlara sebep olabilmektedir. Amid halkından Ayșe ve Şerife hanımlar dîvân-ı hümâyûn'a müracaat ederek, Ayşe Hanım'ın babası ve Şerife Hanım’ın erkek kardeşi olan Seyyid Ali'nin vefatı sebebiyle mirasın kendilerine intikal ettiğini ve aradan on beş yıl geçtiğini beyan etmişlerdir. Ancak Amid halkından Hatice adlı hanım Seyyid Ali adlı şahıstan kalan miras mallarından hisse istemesi ve sürekli huzursuzluk çıkarması sebebiyle Hatice Hanım'ın haksız istek ve müdahalesinin men edilmesi için 22 Temmuz 1723 tarihinde Amid kadısına hüküm gönderilmiştir. ${ }^{90}$ Amid halkından Hızır Bey'in vefatı sebebiyle mirası olan bir ev, çocukları Ömer Ağa'ya ve kardeşi Abdullah'a intikal etmiștir. Ömer Ağa ve Abdullah kendilerine intikal eden evi aralarında hisseli şekilde paylaştıktan sonra Ömer Ağa şehir dışında olduğu bir zamanda hissesinin olduğu evi kardeși Abdullah başkasına satmıştır. Ömer Ağa Amid kazâsı'na geri döndüğü ve hissesini talep ettiğinde kardeșinin ödemeye yanaşmamasından dolayı 25 Şubat 1743'de dîvân-ı hümâyûn'a başvurmuş, meselenin halledilmesi için Diyarbekir valisine ve mollasına hüküm yazılmıştır. ${ }^{91}$ Yine Amid kazâsı halkından Abdülkerim adlı şahıs 1 Şubat 1747'de divana başvurarak, babası Gaffur'dan kendisine ve kardeşleri Ahmet, Mustafa ve Mehmet'e intikal eden ev ve eşyalardan hissesine düşen miktarı almak istediğinde kardeşleri Ahmet ve Mustafa “ kendü hisselerin zaptına kanaat itmeyüb” miras evini ve eşyalarını alarak Abdülkerim'in hissesini vermediklerinden, mirastan kendi hissesine düşenin alınması için Diyarbekir valisine ve kadısına hüküm yazılmıştır. ${ }^{92}$ Amid halkından Ümmügülsüm Hanım, babası Hüseyin' in vefatı sebebiyle kendisine ve erkek kardeşi Mehmet'e intikal eden terekeyi, kardeşi Mehmet " kendü hisselerin ahzına kanaat itmeyüb bunun hissesin dahi hilaf-ı şer'i şerif fuzuli zapt” ettiği hissesini almak istediğinde kardeşi Mehmet'in çeşitli bahaneler öne sürerek

87 BOA. A. DVNSAHK. DB. d. 2, s. 132.

88 BOA. A. DVNSAHK. DB. d. 3, s. 33.

89 BOA. A. DVNSAHK. DB. d. 4, s. 6.

90 BOA. A. DVNS. ŞKT. d. 80 , s. 8.

91 BOA. A. DVNSAHK. DB. d. 1, s. 18.

92 BOA. A. DVNSAHK. DB. d. 1, s. 103. 
ödemeye yanaşmadığından erkek kardeşi Mehmet'ten hissesinin alınması için 13 Eylül 1778 tarihinde dîvân-ı hümâyûna müracaat etmiştir. ${ }^{93}$

Görüldüğü üzere Amid kazâsı'nda halkın miras taksimi ve ardından yaşanan meseleler konusunda en çok şikâyet ettiği konuların başında kendi hissesine düşen miktara kanaat etmeme veya miras malını zabtetme gelmektedir. Halk, diğer meselerlerde olduğu gibi miras konusunda da Amid mahkemesinde sorununa çözüm bulamadığı takdirdeDîvân-ı Hümâyûn'u sıkça kullanmakta ve bu meselelere çözüm aramaktadır.

\section{6- Vakıflar ile İlgili Olaylar}

Vakıf müessesesinin, insanla beraber mevcut olan karşılıklı dayanışma ve başkasına iyilik yapma duygusunu, hukuki statüye kavuşturan ve ona süreklilik kavramı sağlayan, milletlerin sahip olduğu manevi güç ve değerlerin tanımlanmasına yardımcı tüzel kişiliğe sahip demokratik, sivil bir toplum kuruluşu olduğunu söylemek mümkündür. ${ }^{94}$ Vakıf müessesesi, Osmanlı medeniyetinin gelişmesinde ve toplumsal ihtiyaçların karşılanmasında çok önemli roller üstlenmişlerdir. Gündelik hayat içerisinde dini, sosyal, kültürel, eğitim, sağlık vb. alanlarda halkın ihtiyaçlarına cevap veren vakıflar, zaman içerisinde bazı bozulmalara ve yolsuzluklara sahne olmuştur. Özellikle XVIII. yüzyılda Osmanlı Devleti'nin içinde bulunduğu siyasî ve sosyo-ekonomik durum vakıfların idaresi ve işleyişine de etki etmiştir. Vakıflarda yaşanan yolsuzluk ve bozulmaların engellenmesiiçin padişahlara birçok kez rapor sunulması hatta vakıfların durumunun yerinde kontrol edilmesi için özel müfettişlerin gönderilerek gerekli tedbirlerin alınması bozulma ve yolsuzlukları engelleyememiştir. ${ }^{95}$

Konu edilen dönemde Amid kazâsı'ndaki vakıflarda meydana gelen yolsuzluk ve bozulmalara dair farklı türden olaylara rastlanmaktadır. Bu olaylar içerisinde vakıf parasının veya mallarının zimmete geçirilmesi, vakfiye şartlarına uyulmayarak vakfın zarara uğratılması, vakfa ait olan arazi, dükkân, ev vb. yerlerin zapt edilmesi, vakıfta görevli kişilerin görevlerini yapmaması veya görevlerini aksatması gibi sorunlar ön plana çıkmaktadır.

Amid kazâsı'ndaki vakıflarda meydana gelen yolsuzlukların başında vakıf malının zapt edilmesi veya vakfa ait mal ve paraların zimmete geçirilmesi gelmektedir. Amid'deki Şehit Mehmet Paşa vakfının mütevellisi İbrahim Hanzade İsmail 23 Haziran 1743 tarihinde divana şikâyette bulunarak, gelirleri Şehit Mehmet Paşa vakfına ait olan ve Hasan Paşa Hanı'nda bulunan vakıf dükkânlarını Amid halkından Ahmet adlı şahıs ve oğullarının zapt ettiğini söylemiştir. Vakıf dükkânlarının zaptının engellenerek vakfa geri alınması için Diyarbekir valisine ve Amid kadısına hüküm yazılmıștır. ${ }^{96}$ Amid'deki Ablak Mescidi'nin mütevellisi olan Seyyid İsmail 29 Ekim 1780'de Dîvân-ı Hümâyûn'a şikâyette bulunarak, mescide ait vakıf değirmenlerini Amid halkından bazı kimselerin zapt ettiğini, değirmenleri geri almak için

93 BOA. A. DVNSAHK. DB. d. 3, s. 329.

94 Nazif Öztürk, “Osmanlı Döneminde Vakıflar”, Türkler, Yeni Türkiye Yayınları, Ankara 2002, X, s. 434; Nazif Öztürk, Türk Yenileşme Tarihi Çerçevesinde Vakıf Müessesesi, TDV Yayınları, Ankara 1995, s. 19; Ziya Kazıc1, İslam Tarihi, MÜİFVY, Cilt. 10, İstanbul 1995, s. 426.

95 Bahaeddin Yediyıldız, XVIII. Yüzyılda Türkiye'de Vakıf Müessesesi, TTK Yayınları, Ankara 2003, s. 192-195. 96 BOA. A. DVNSAHK. DB. d. 1, s. 29. 
talepte bulunduğunda muhalefet ile karşılaşarak alamadığını bildirmiştir. ${ }^{97}$

Bu dönemde vakıf arazilerinin zapt edilmesi gündelik hayatta önemli sorunlara sebep olmaktadır. Mesela Amid'de vaki Zinciriye Medresesi vakfı mütevellisi Seyyid Gaffur 28 Mayıs 1787 tarihinde divana başvurarak, Garb-i Amid Nahiyesi'nde bulunan birkaç karyedeki vakıf arazilerini bazı kimselerin zapt ederek ziraat yaptıklarından zapt edilen vakıf arazilerin vakfa alınmasını istemiştir. ${ }^{98}$

Yaşanan usulsüzlükler sadece vakfa ait gayrimenkullerin zapt edilmesi ile sınırlı değildir. Vakfa ait paraların zimmete geçirilmesi ile ilgili olaylara da rastlanılmaktadır. Mesela Amid kazâsı'nda vaki Veli Kethüda Camii'sinin mütevellisi Mustafa adlı şahıs 14 Aralık 1785'de mahkemeye başvurarak, Veli Kethüda Camii vakfına ait olan 365 kuruşu Amid halkından İbrahim Efendi'nin el koyarak zimmetine geçirdiğini söylemiş ve İbrahim Efendi'nin zimmetinde olan vakıf parasının vakfa geri alınmasını talep etmiştir. ${ }^{99}$ Vakıf parasının zimmete geçirilmesi ile ilgili başka bir hadisede; Amid'de Dağ Kapısı haricinde bulunan Hacı Mehmet vakfının mütevellisi Seyyid Mehmet Halife 19 Mayıs 1786'da divana müracaat ederek, Hacı Mehmet vakfının senelik kira geliri olan 250 kuruşu Amid halkından İsmail Ağa'nın zapt ederek zimmetine geçirdiğinden vakıf parasının tahsil edilmesini istemiştir. ${ }^{100}$

Vakıflarda yaşanan yolsuzluklara başka bir örnek vakfiye şartlarına uyulmaması ve bu sebeple vakıfların çeşitli şekillerde zarara uğratılmasıdır. Mesela Amid'de bulunan Hüsrev Paşa Camii vakfının nazırı Seyfullah ve kâtibi Ahmet 23 Şubat 1755'de divana şikâyette bulunarak, vakıf mütevellisinin vakıf paralarını vakfiye şartına göre harcamayarak vakfı zarara uğrattığını bildirmişlerdir. Şikâyet sebebiyle Anadolu muhasebesi defterlerine bakılarak, vakfiye şartlarına göre paranın harcanması ve daha önce sarf edilen paranın mütevelliden tahsil edilmesi için hüküm yazılmıştır. ${ }^{101}$ Vakfiye şartlarına uymayarak vakfın zarara uğratılması ile ilgili Hüsrev Paşa Camii vakfının imamı Hafız Molla Mehmet Halife 21 Ocak 1767'de divana başvurarak, vakfın mütevellisi Hacı İsmail'in vakfa ait emlakları vakfiye şartlarına aykırı șekilde kiraya vermeyip, vakfı zarara uğrattığından müdahale edilmesi için Diyarbekir valisine ve Amid naibine hüküm gönderilmiștir. ${ }^{102}$

Vakfiye şartlarına uyulmaması vakıflara olduğu kadar kişilere de çeşitli zararlar verebilmektedir. Vakfiyelerde kişilere veya kurumlara tahsis edilen gelirin verilmemesi gündelik hayatta önemli sorunlara sebep olmuştur. Mesela Amid kazâsı'na tabi Ali Pınarı karyesinde bulunan ve ismi belirtilmeyen Camiinin imamının vefat etmesi sebebiyle imamlık görevi Abdi'ye intikal etmiştir. Abdi adlı şahıs bu görevi bir yıldan fazla bir süre yapmasına rağmen Camiideki imamlık hizmetine karşılık vakıf tarafından kendisine ödenmesi gereken buğdayın vakıfmütevellisi tarafından ödenmediğinden şikâyetçi olmuştur. Vakıf mütevellisinin, Abdi'nin hizmetine karşılık gelen buğdayı ödemesi ve muhalefet etmemesi için Amid kadısına

\footnotetext{
97 BOA. A. DVNSAHK. DB. d. 4, s. 14.

98 BOA. A. DVNSAHK. DB. d. 4, s. 159.

99 DŞS. 352, 62; BOA. A. DVNSAHK. DB. d. 4, s.129.

100 BOA. A. DVNSAHK. DB. d. 4, s. 139.

101 BOA. A. DVNSAHK. DB. d. 2, s. 11.

102 BOA. A. DVNSAHK. DB. d. 3, s. 151.
} 
hüküm yazılmıştır. ${ }^{103}$ Yine Amid kazâsı ahalisinden Seyyid Hacı İdris 29 Ekim 1780'de divana şikâyette bulunarak, Hacı Mustafa adlı şahsın hayatta iken vakfettiği emlakın kira gelirinin bir kısmının vakfiye şartı gereği kendisine tahsis edilmesine rağmen vakıf mütevellisinin kira gelirinden kendi payına düşen miktarı vermediğinden şikâyet etmiştir. ${ }^{104} \mathrm{Amid}$ kazâsı'na tabi Ali Pınarı karyesindeki bir evin kirası Amid'de bulunan Mehmet Paşa vakfının geliri iken evde kiracı olarak oturan Mehmet adlı şahıs "bu menzil benim malımdır" diyerek vakfiyede belirtilmesine rağmen kirayı ödemediğinden, vakıf mütevellisi 12 Nisan 1746 tarihinde vakfa ait kira gelirinin tahsil edilmesi istenmiştir. ${ }^{105}$

Vakfiye şartı gereği vakıflarda görevli kimselerin vazifelerini yapmamaları veya vakıftaki görevlerini aksatmaları gündelik hayatta sorunlara yol açmaktadır. Amid'de vaki Hüsrev Paşa Camii vakfının imaretinde günlük iki akçe vazife ile görevli olan Abdülhabib'in görevini yapmadığı hatta vakıftan yeni vazifeler talep ederek vakfı ve imareti zor durumda bıraktığından, vakıf mütevellisi Ahmet'in şikâyeti üzerine durumun düzeltilmesi ve vakfiye şartı gereği Abdülhabib'in görevini yaparak yeni vazife talebiyle müdahalesinin engellenmesi için 2 Mayıs 1764'de Amid naibine hüküm gönderilmiştir. ${ }^{106}$

Vakfiyelerde belirtilmesine rağmen, vakıfta görevli kimselerin vazifelerinin mütevelliler tarafından kendilerine verilmemesi de sorunlara sebep olmaktadır. Amid'de bulunan Hasan Paşa Camii'nde günlük yirmi akçe vazife ile dua-gû ve ferraş olan Seyyid Abdüllatif 26 Ekim 1746 tarihinde divana müracaat ederek, vakıftaki görevinin vakıf mütevellisi tarafından verilmediğini söyleyerek şikâyetçi olmuştur. ${ }^{107}$

Yukarıdaki örneklerden görüldüğü üzere incelenilen dönemde Amid kazâsı'nda vakıflar hususunda meydana gelen olaylar çok çeşitlidir. XVIII. yüzyılın siyasi, sosyal, ekonomik ve kültürel yapısı vakıfların işleyişine doğrudan veya dolaylı olarak etki etmiş olsa da Amid kazâsı'nda vakıflar ile ilgili meselelerin neredeyse tamamı insan kaynaklıdır. Vakıf mallarının veya parasının zimmete geçirilmesi, vakıfçalışanlarının ücretlerinin verilmeyişi veya vakıfların çeşitli sebepler ile zarara uğratılmasının arkasında yatan temel sebep insandır. İncelenilen dönemde kazâ merkezi ve karyelerdeki vakıflarda meydana gelen meseleler çok çeşitli olsa da özellikle vakıf paralarının veya gayrimenkullerinin zimmete geçirilmesi ile vakfiye şartlarına uyulmayarak vakıfların zarara uğratılması konusu ön plana çıkmaktadır. Devletin Amid kazâsı'ndaki vakıflarda meydana gelen her türlü meselenin çözülmesinde Amid/ Diyarbekir valisine, kadısına ve naibine görev vererek vakıflarda nizamın sağlanması için hem devlet adamları hem de hukuk adamları vasıtasıyla gayret sarf ettiği arşiv vesikalarından anlaşılmaktadır.

\section{7- Arazi Anlaşmazlıkları}

Gündelik hayatta meydana gelen olaylardan bir diğeri de arazi anlaşmazlıklarıdır. Bu olayların temel sebepleri kişi veya kişilerin tasarruf ettikleri arazilerin mülkiyet hakkına

\footnotetext{
103 BOA. A. DVN. ŞKT. d. 1006, s. 3.

104 BOA. A. DVNSAHK. DB. d. 4, s. 13.

105 BOA. A. DVNSAHK. DB. d. 1, s. 83.

106 BOA. A. DVNSAHK. DB. d. 3, s. 52.

107 BOA. A. DVNSAHK. DB. d. 1, s. 98.
} 
yapılan sebepsiz müdahaleler ile arazinin kişi ya da kişiler arasında paylaşılamamasından ileri gelmektedir. Bu olaylar genellikle mahallinde çözülemediğinden Dîvân-ı Hümâyûn'a intikal etmektedir. Arazi ile ilgili şikâyetlere çözüm getirmek için ilgili defterlere bakılmaktadır. ${ }^{108}$

Amid kazâsı'nda arazi ve su anlaşmazlıkları ile ilgili arşiv kayıtlarına yansıyan elli bir olay tespit edilebilmiştir. Elbette bir asır boyunca meydana gelen olay sayısı, tespit edilebilen sayı ile sınırlı olmayıp konu hakkında genel bir fikir vermesi bakımından önemlidir. Bu dönemde tespit edilebilen elli bir olayın otuz dördü arazi anlaşmazlıkları, sınır anlaşmazlığı ve arazinin mülkiyet hakkına dışarıdan yapılan müdahalelere, on yedisi su anlaşmazlığına dair olayları ihtiva etmektedir.

Arazi anlaşmazlığına dair davaların büyük bir kısmını, karyelerde meydana gelen olaylar oluşturmaktadır. Bu olaylar içerisinde iki kişi arasında meydana gelen arazi anlaşmazlığına dair kayıtlar olabildiği gibi, iki veya daha çok karye halkının şikâyetleri de bulunmaktadır. $\mathrm{Bu}$ olaylara dair örneklerden bazıları şu şekildedir. Karyeler arasında meydana gelen arazi anlaşmazlığına dair 22 Mayıs 1746 tarihli bir olayda Amid kazâsı'na bağlı Göze Karyesi halkı topluca dîvân-ı hümâyûna müracaat ederek, yine Amid kazâsı'na bağlı Akran Karyesi halkından bazı kimselerin "sizin tarlalarınız bizim karyemiz arazisindendir size zapt itdirmeziz" diyerek tarlarını zapt ettiklerinden müdahalenin engellenmesi ve zapt edilen yerlerin Göze Karyesi'ne geri alınması için Diyarbekir valisine ve kadısına emir gönderilmişti. ${ }^{109}$

Bu dönemde arazinin mülkiyet hakkına yapılan müdahaleler kişi veya kișiler arasında soruna sebep olmaktadır. Amid halkından Hüseyin adlı sipahi Şark-i Amid Nahiyesi'nde mutasarrıf olduğu tîmâr toprağını İbrahim adlı sipahinin "senin karyen benim mutasarrıf olduğum karyedendir zapt ederim" diyerek zapt etmesinden dolayı 15-25 Ağustos 1749 tarihinde divana başvurarak şikâyetçi olmuştur. Olayın çözülmesi için defterhanede bulunan ilgili defterlere bakılarak, toprağın hala Hüseyin sipahi üzerinde kayıtlı olduğu tespit edildiğinden İbrahim sipahinin müdahalesinin men edilmesine karar verilmiştir. ${ }^{110}$ Yine Mehmet adlı sipahinin mutasarrıf olduğu mezraayı Mustafa sipahi "senin mutasarrıf olduğun mezraa benim zeâmetim mülhakatındadır" diyerek haksız yere zapt etmiştir. Ancak defterhanede bulunan ilgili defterlere bakılarak mezraanın Mehmet sipahi üzerine kayıtlı olduğu tespit edildiğinden Mustafa adlı sipahinin müdahalesinin sona erdirilmesi için 1 Nisan 1756 tarihinde hüküm gönderilmişti. ${ }^{111}$

\section{8-Su Meseleleri}

Gündelik hayatta meydana gelen olaylardan bir diğeri de su anlaşmazlıklarıdır. Ayanlar çağı olarak da bilinen on sekizinci yüzyılda Osmanlı Devleti su kaynaklarını dilediği gibi yönetememiştir. Özellikle merkezi otoritenin gücünün azaldığı ve su kaynakları üzerindeki kontrol ve denetimin daha zayıf olduğu kırsal bölgelerde bu kaynaklar ve onlarla beslenen

\footnotetext{
108 Gürkan Cevger, 1 Numaralı ve 1155-1158/1742-1745 Tarihli Karaman Ahkâm Defteri’nin Transkripsiyonu ve Değerlendirilmesi (s.1-60), (Yayımlanmamış Yüksek Lisans Tezi), Atatürk Üniversitesi Sosyal Bilimler Enstitüsü, Erzurum 2012, s. 24.

109 BOA. A. DVNSAHK. DB. d.1, s. 86.

110 BOA. A. DVNSAHK. DB. d.1, s. 164.

111 BOA. A. DVNSAHK. DB. d.2, s. 55.
} 
arazilerde bazı yeni güç odakları devreye girmiştir. Bu durum çeşitli hak ihlallerine sebep olması nedeniyle kişi veya kişileri karşı karşıya getirmiştir. Bu sebeple XVIII. yüzyılda Osmanlı mahkemeleri su anlaşmazlığı ile ilgili çeşitli şikâyetçilerin de görüşüldüğü yerler haline gelmiştir. $^{112}$

Amid kazâ merkezi ve karyelerde meydana gelen su anlaşmazlıklarının ana sebebi kişilerin tasarrufunda olan suların eski yerlerinden çevrilmesi veya ortak kullanılan sulara yapılan çeşitli müdahaleler nedeniyle kişilerin veya kurumların zor durumda kalmalarından kaynaklanmaktadır. İncelenilen dönemde su anlaşmazlığına dair arşiv kayıtlarına yansıyan kazâ merkezinde altı, karyelerde iki olay tespit edilebilmiştir.

XVIII. yüzyılda Amid kazâ merkezindeki su anlaşmazlığına dair meseleler şu şekildedir. Amid'de bulunan Hüsreviye ve Gayblar Mahallesi ahalilerinden Hasan oğlu Molla Mustafa, Osman oğlu Seyyid Mustafa, Mehmet oğlu Ahmet, İbrahim oğlu Seyyid Osman vesair şahıslar 3 Ekim 1723 tarihinde mahkemeye başvurarak Amid'de bulunan Gayblar adlı çeşmenin suyunun Semanzâde Mehmet Çelebi'nin evine fazla şekilde aktığını ve haksızlık olduğunu bildirmişlerdir. Mimarbașı, suyolcular ve bilirkişi tarafından ayar yapılarak su akışının eski haline getirilmesi sağlanmıștır. ${ }^{113}$ Amid halkından Feyzullah Rum Kapısı dıșında bulunan bahçesini sularken bazı kimselerin haksız şekilde suya müdahale ettiklerini ve kendisinden "hakk-ı saki" adı altında para talep ettiklerinden 27 Mart 1743'de divana müracaat ederek şikâyetçi olmuştur. ${ }^{114}$ Amid halkından Mehmet de 10 Ocak 1749'da divana şikâyette bulunarak, Ahmet Haşim Mahallesi'nde bulunan evine gelen suyuna yine Amid halkından Hacı İsmail'in haksız sebepler ile müdahale ettiğini ve evine gelen suyu "mecra-yı kadîmden ihraç idüb" kendi evine çevirdiğini söyleyerek haksızlığın giderilmesini talep etmiştir. Suyun eski haline döndürülmesi için Diyarbekir valisine ve Amid monlasına hüküm gönderilmiştir. ${ }^{115}$ Amid halkından Hacı Mustafa Ağa, kendi evine gelen suya Amid halkından bazı kimselerin "ol sudan bir kıt'a ve kendü menzilimize harman etdirirüz" diyerek müdahale etmelerinden dolayı divana şikâyette bulunmuş ve meselenin çözülmesi için 31 Mart 1756 tarihinde Diyarbekir valisine ve Amid nâibine hüküm yazılmıștır. ${ }^{116}$ Amid'de Debbağhane Camii civarında ikâmet eden Hacı Hasan adlı şahıs 13 Aralık 1756'da divana başvurarak, evine gelen Balıklı Suyu'na Feto ve Samas adlı zimmîlerin müdahale ettikleri ve suyu kendi evlerine çevirerek kendisini mağdur ettiklerini söyleyerek müdahalenin engellenmesi istemiştir. ${ }^{117}$ Yine Hüseyin adlı şahsın bahçesine gelen suyu, Hacı Hamza'nın kendi bahçesine çevirmesi sebebiyle Hüseyin'i mağdur ettiğinden haksızlığın giderilmesi ve suyun eski yönüne çevrilmesi için 11 Şubat 1775 'de hüküm gönderilmiștir. ${ }^{118}$

Bu dönemdekaryelerde meydana gelen su anlaşmazlığına dair olaylar şu şekildedir. Şark-i Amid Nahiyesi'ne bağlı Göbe karyesinden Amolu, Harak ve bazı gayrimüslimler

\footnotetext{
112 Zafer Karademir, “Osmanlı Sosyo-Ekonomik Yaşamında Su: 18.Yüzyıl Eyâlet-i Rum Örneği”, TİD, 29(1), İzmir 2014, s. 190. 
27 Mayıs 1750 tarihinde Dîvân-ı Hümâyûn'a müracaat ederek, karyelerinde ziraat edecek suları olmadığından karyeleri civarında bulunan ve kimsenin mülkü olmayan suyu, kendi karyelerine ve tarlarına çevirdikleri ve kimseye zararları yok iken, bazı kimselerin sularına müdahale ederek karye ahalisine rahatsızlık verdiklerini söylemişler ve kendilerine yapılan müdahalenin engellenmesi için hükm-i hümâyûn gönderilmesini rica etmişlerdir. ${ }^{119} \mathrm{Amid}$ kazâsı'nda meydana gelen su anlaşmazlıklarına başka bir örnek iki karye arasında bulunan suyun paylaşılamamasıdır. Garb-i Amid Nahiyesi'ne bağlı Akımi karyesinden Ahmet ve Mehmet Haşim 4 Aralık 1745'de Dîvân-ı Hümâyûn'a müracaat ederek, karyelerinin sahibi olduğu Karapınar adlı suya yine Amid kazâsı'na bağlı Karaviran karyesi ahalisinin "ol su tokuz gün tokuz gice sizin ve sekiz gün sekiz gice bizimdür" diyerek müdahale etmelerinden şikâyetçi olmuşlardır. Yapılan inceleme sonucunda Karaviran karyesi'nin su ile hiçbir alakası olmadığından, müdahalelerinin engellenmesi için Diyarbekir valisine ve Amid kadısına hüküm gönderilmiştir. ${ }^{120}$ Aradan otuz dört sene geçtikten sonra iki karye ahalisi Karapınar adlı suyun paylaşılamaması sebebiyle tekrar karşı karşıya gelmişlerdir. Garb-i Amid Nahiyesi'ne tabi Karaviran karyesi halkı kendilerine ait olduğunu iddia ettikleri Karapınar adlı suya, Akımi karyesi halkından bazı kimselerin çevre karyelerden insanlar ile bir olarak suyun yönünü çevirdikleri bu sebepten dolayı karyedeki değirmenlerine su gitmediğinden zarara uğradıklarını söyleyerek, 17 Nisan 1779 tarihinde Dîvân-ı Hümâyûn'a başvurarak Karacaviran karyesi halkından şikâyetçi olmuşlardır. ${ }^{121}$

Yukarıda verilen örneklerden görüldüğü üzere Amid kazâsı'nda meydana gelen arazi veya su anlaşmazlıklarının çözülmesi için devletin doğrudan olaya müdahil olduğu anlaşılmaktadır. Amid halkının arazi meselelerinin çözümü için Dîvân-ı Hümâyûn'a başvurduğu ve devletin bu meselelere çözüm getirirken genellikle defterhanede bulunan ilgili defterlere bakarak sorunun halledilmesine çalıştığı anlaşılmaktadır. Yine bu dönemde Amid kazâ merkezi ve karyelerde meydana gelen su anlaşmazlıkları genellikle suyun yönünün çevrilmesi sebebiyle kişilerin mağdur olması gibi ferdi olaylardan olabildiği gibi nadir de olsa karyeler arasında cereyan eden geniş çaplı meselelerin de olduğu görülmektedir.

\section{9- Vergiler İle İlgili Sorunlar}

XVIII. yüzyılda Amid kazâ merkezi ve karyelerde yönetici sınıfın vergiler hususunda halka keyfi tutum ve davranışları bulunmaktadır. Vergilerin toplanması esnasında yönetici zümrenin usulsüz vergi talepleri karşısında zor durumda kalan halk, haksızlığın giderilmesi için mahkemelere veya dîvân-ı hümâyûn'a başvurmaktadır. Bu şikâyetlerin sebepleri yöneticilerin usulsüz vergi talepleri, halkın vergisini vermesine rağmen yönetici sınıfın tahsil ettiği vergiye kanaat etmeyerek halktan fazla vergi almak istemesi ve karye ya da mahalle halkının verginin ödenmesi esnasında kendi aralarında yaşadıkları hadiselerdir.

Konu edilen dönemde kazâ merkezi ve karyelerde meydana gelen haksız vergi talepleri ile ilgili hadiselerden bazıları şöyledir. Amid'de yaşayan gayrimüslim halk topluca Dîvân-ı Hümâyûn'a müracaat edip, ödemeleri gereken ispenç vergilerini zabitlerine tamamen ödemelerine rağmen, zabitlerinin kanaat etmeyerek haksız şekilde iki kuruş ayrıca da

119 BOA. A. DVNSAHK. DB. d.1, s. 182-183.

120 BOA. A. DVNSAHK. DB. d.1, s. 75.

121 BOA. A. DVNSAHK. DB. d.3, s. 347. 
sarrafiye namıyla yirmişer akçe fazladan vergi talep ettiğinden şikâyetçi olmuşlardır. Zabitlerinin haksız vergi talebinin men edilmesi için 3 Kasım 1719 tarihinde Diyarbekir valisine ve kadısına hüküm yazılmıştır. ${ }^{122}$ Yine Amid kırsalında yaşayan konar-göçer Hoyri Aşireti sakinleri de vergilerini oturdukları yerin zabitine vermelerine rağmen Amid halkından ve erbab-ı tîmârdan Zeki ve Osman'ın çeşitli bahaneler öne sürerek 100 kuruş fazladan vergi aldıklarını söyleyerek şikâyetçi olmuşlardır. Hoyri Aşireti'nden vergi talebinin men edilmesi ve adaletin sağlanması için 26 Mart 1725'de Amid kadısına hüküm gönderilmiştir. ${ }^{123}$ Garb-i Amid Nahiyesi'ne bağlı Zirsolna karyesi halkı 3 Ağustos 1742 tarihinde Dîvân-ı Hümâyûn'a başvurarak, öşür vesair vergilerini karyelerinin zabitine tamamen ödemelerine rağmen karye zabitinin kanaat etmeyerek yeniden öşür istemesi ve karye halkına çeşitli zulümler yapmasından şikâyet etmişlerdir. ${ }^{124}$ Yine tüccar tâifesinden Molla Bekir ve bazı tacirler bac vergilerini vermelerine rağmen kendilerinden tekrar bac vergisi talep edildiğini söyleyerek 15 Nisan 1743 tarihinde Dîvân-ı Hümâyûn'a şikâyette bulunmuşlardır. ${ }^{125}$

Bac vergisinin haksız talebiyle ilgili 25 Mayıs 1743 tarihli başka bir hadisede Amid halkından Mustafa, Eğil Sancağı'nda bulunan üzüm bağından elde ettiği mahsulünün öşrünü zabitlerine ödemiş geri kalan üzüm ve pekmezini Amid kazâsı'na getirirken kale kapısında kendisinden bac vergisi talep edildiğini söyleyerek haksızlığın giderilmesini istemiștir. ${ }^{126} \mathrm{Amid}$ kazâsı'na tabi ismi belirtilmeyen karye halkından ve Döğerli Cemaati'nden Ramazan oğlu Hasan, Hüseyin oğlu Hüseyin, Seyyid oğlu Mehmet ve Hasan oğlu Mustafa ve karyelerindeki bazı zimmîler vergilerini karyeleri zabitine vermelerine rağmen, zabitlerinin aldığı vergiye kanaat etmeyerek fazladan vergi istediğinden şikâyet etmişlerdir. Fazladan vergi isteğinin engellenmesi ve meselenin halledilmesi için 2 Nisan 1746 'da hüküm gönderilmiştir. ${ }^{127}$ Yine Amid halkından Osman ve Seyyid İbrahim de 15 Nisan 1763 tarihinde divana müracaat ederek, tarlalarından elde ettikleri mahsullerinin öşrünü sipahilerine verdiklerini ancak sipahileri olan Hacı Hasan’ın kanaat etmeyerek kendilerinden tekrar tekrar öşür talep ettiğini söylemişlerdir. ${ }^{128}$

Haksız vergi talebi ile ilgili diğer bir mesele vergiden muaf kimselerden vergi talep edilmesidir. $\mathrm{Bu}$ şikâyetlerin başında bazı vergilerden muaf olan seyyidlerden resm-i râiyyet $^{129}$, adet-i ağnam ${ }^{130}$, tekâlif-i şakka ${ }^{131}$, vb. vergilerin talep edilmesi veya avârız vergisi ödemek zorunda olmayan kimselerden vergi istenmesi gelmektedir. Amid halkından Ağya

\footnotetext{
122 BOA. DVNS. ŞKT. d. 83, s. 182.

123 BOA. DVNS. ŞKT. d. 105, s. 126.

124 BOA. A. DVNSAHK. DB. d.1, s. 1.

125 BOA. A. DVNSAHK. DB. d.1, s. 28.

126 BOA. A. DVNSAHK. DB. d.1, s. 30.

127 "karye-i mezkûrun defterinden mukayyedrâiyyet ve râiyyet oğullarından olub üzerlerine edâsı lazım gelen hukuk ve rüsumatları kanun ve defter mucibince virmeğe rızaları olub ziyade talebiyle teâddî ve rencîde olunmaları icap etmez iken karyeleri zabiti olanlar kanun ve defter mucibince almağa kanaat itmeyüb kanun ve defter ziyade mütâlebesiyleteâddî ve tecavüz ve rencide itmekten hâli oldukları” BOA. A. DVNSAHK. DB. d.1, s. 84.

128 BOA. A. DVNSAHK. DB. d.3, s. 7.

129 BOA. A. DVNSAHK. DB.d.1, 84; BOA. A. DVNSAHK. DB. d.2, 64; BOA. A. DVNSAHK. DB. d.3, 119 , 236, 237, 242, 271, 310, 311, 319, 319, 365; BOA. A. DVNSAHK. DB.d.4, 66, 67; BOA. A. DVNSAHK. DB. d.5, 5, 8.

130 BOA. A. DVNSAHK. DB.d.1, 104, 232; BOA. A. DVNSAHK. DB. d.2, 220/4., A. DVNSAHK. DB. d.3, 222, 243, 266; BOA. A. DVNSAHK. DB. d.4, 19; BOA. A. DVNSAHK. DB. d.5, 27.

131 BOA. A. DVNSAHK. DB.d. 3, 20, 131, 289, 311, 391; BOA . A. DVNSAHK. DB. d.4, s. 66.
} 
adlı gayrimüslim cizye vergisini ödediği ve üzerinde kayıtlı emlak ve arazi olmaması bu sebepleavârız vergisinden muaf olmasına rağmen kazâ ahalisinden bazı kimselerin vergi miktarını azaltmak için "bizimle birlikte hisse ver" diyerek rahatsızlık verdiklerini söyleyerek Dîvân-ı Hümâyûn’a başvurmuştur. Meselenin halledilmesi için 24 Nisan 1724 tarihinde Amid kadısına ve Diyarbekir mütesellimine hüküm yazılmıştır. ${ }^{132}$ Amid kazâsı'na bağlı Ali Pınarı karyesinden Muhammed ve Ömer 31 Ağustos 1744 tarihinde divana müracaat ederek, emlak ve arazileri olmamasına rağmen karye halkının "bizimle birlikte avârız vergisine ortak olun" diyerek rahatsızlık verdiklerinden şikâyet etmişlerdir. ${ }^{133}$

Yine Amid halkından Ahmet ve İsmail adlı şahıslar 20 Haziran 1784 tarihinde Dîvân-ı Hümâyûn'a müracaat ederek, kendilerinin Amid kazâsı'na bağlı Şarabi karyesi halkından olmadıkları halde, karyenin sipahileri olan Numan ve Mustafa'nın "siz bizim râiyyetimizsiniz sizdenresm-irâiyyetalırım" diyerekusulsüzvergitalepetmelerindenşikâyetetmişlerdir. ${ }^{134}$ Amid kazâsı halkından Seyyid Bekir 22 Ocak 1775'de Dîvân-ı Hümâyûn'a başvurarak, zaimleri olan Osman Beşe'nin "sen benim mutasarrıf olduğum hass-ı karyelerinden (...) karyesinin reâyasındansın senden resm-i râiyyet alırum” diyerek kendisinden kanuna aykırı şekilde vergi talep edildiğini söylemiștir. ${ }^{135}$ Amid kazâsı'ndaki seyyidlerden Seyyid Süleyman, Seyyid Bekir, Seyyid Nebi, Seyyid Mehmet, Seyyid Hasan, Seyyid Musa, Seyyid Hüseyin vesair kimseler üzerlerine edası lazım gelen imdad-ı hazeriye, avârız vesair vergilerini ödedikleri halde, Amid yöneticileri taraflarından resm-i râiyyet ve tekâlif-i şakka talebiyle rahatsız edildiklerini söylemişlerdir. Meselenin halledilmesi ve usulsüz vergi talebinin derhal men edilmesi için Amid kadısına 20 Haziran 1784 tarihinde hüküm gönderilmiştir. ${ }^{136}$ Amid halkından Seyyid Mustafa, Seyyid Abdulgaffar ve yeğenleri Seyyid Hasan şahısların, kendileri için besledikleri yüz ellişer adet koyunlarından adet-i ağnam vergisi almak kanunsuz iken, vergi tahsildarları tarafından kendileri için besledikleri koyunlardan adet-i ağnam vergisi talebiyle rahatsız edildikleri söyleyerek şikâyetçi olmuşlardır. Müdahalenin engellenmesi ve haksız vergi talebinin reddedilmesi için 13 Nisan 1792'de Amid kadısına hüküm gönderilmiştir. ${ }^{137}$

Kazâ merkezi ve karyelerde halkın vergiler hususunda en çok şikâyet ettiği meselelerden bir diğeri de halktan usulsüz şekilde toplanan tekâlif-i şakka ${ }^{138}$ vergisidir. Osmanlı Devleti'nde örfi vergiler esas itibariyle geçici ve olağandışı durumlarda, savaşlar ve iç sorunların çözülmesi için konulmuş bir vergi grubudur. Ancak bu vergilerin daha sonra "tekâlif kavaidine" aykırı olarak halka yükletilmesi ile birlikte bu vergiler "şakka" olarak anlam bulmuştur. XVIII. yüzyılda bu çeşit vergilerin sayılarının artmasında devlet idaresinin zayıflaması ve paranın dönemin ekonomik göstergelerine bağlı olarak değer kaybetmesi de etkili olmuştur. ${ }^{139}$ Bu vergi

\footnotetext{
132 BOA. A. DVNS. ŞKT. d. 100, s. 230.

133 “zapt ve tasarruflarında hâne-i avârıza bağlı kadîm-i reâya emlâk ve yerleri olmayub tekâlif talebiyle rencide ve remîde olmaları icap etmez iken..." BOA. A. DVNSAHK. DB. d.1, s. 54.

134 BOA. A. DVNSAHK. DB. d.4, s. 92.

135 BOA. A. DVNSAHK. DB. d.3, s. 236.

136 BOA. A. DVNSAHK. DB. d.4, s. 66.

137 BOA. A. DVNSAHK. DB. d.5, s. 8.

138 Kanunnamelerde öngörülmediği ve defterlerde bulunmadığı halde ehl-i örf denilen ve devlet hizmeti yürüten görevlilerce halktan çeşitli adlar altında toplanan vergidir. Ünal, Osmanlı Tarih Sözlügü, 675; Mehmet Zeki Pakalın, Osmanlı Tarih Terimleri ve Deyimleri Sözlügü, MEB Basımevi, İstanbul 1983,III, s. 439.

139 Levent Küçük, “Osmanlı Vergi Hukukunda Avârız Kavramı ve Avârızın İdaredeki Rolü”, (Yayımlanmamış Doktora Tezi), Ankara Üniversitesi Sosyal Bilimler Enstitüsü, Ankara 2007, s. 33-34.
} 
toplanılırken belli bir hukuksal dayanağın ve kaidenin olmamasından dolayı, bu tip vergilerde hak ve adalet anlayışının dikkate alınması söz konusu olmamaktadır. ${ }^{140}$ Osmanlı Devleti'nin bu tür vergilerin alınmasını gayrimeşru sayarak yasadışı ilan etmesi hatta bu vergileri alanları cezalandırması ve halkın şikâyetlerinin sıkı takibatına rağmen, vergi isteyenlerin güç ve otorite sahibi kimseler olması sebebiyle istenilen başarı bir türlü sağlanamamıștır. ${ }^{141}$

Bu dönemde kazâ merkezi ve karyelerde halktan tekâlif-i şakka vergisinin tahsil edilmek istenmesi sebebiyle halk ile yöneticiler arasında yaşanılan sorunlara dair birçok şikâyet örneği bulunmaktadır. ${ }^{122}$ Amid'de bulunan Mustafa Paşa Camii'nin neccarı Melkon 3 Ağustos 1742 tarihinde divana müracaat ederek, ödemesi gereken imdad-ı hazeriye, imdad-ı seferiye ve avârız vergisinden hissesine düşen vergilerini tamamen ödediği halde yöneticiler tarafından "tekâlif-i şakka" adı altında tekrar vergi istendiğini söyleyerek şikâyette bulunmuştur. ${ }^{143}$ Yine Amid halkından Ayos, 30 Eylül 1742 tarihinde Dîvân-ı Hümâyûn'a başvurarak, ödemesi gereken vergilerini tamamen ödediği halde kendisinden yöneticiler tarafından tekâlif-i şakka adı altında vergi istenildiği söylemiştir. ${ }^{144}$ Şark-i Amid Nahiyesi'ne tabi Taraklı, Göble ve Tel-gazi karyelerinin halkı Dîvân-ı Hümâyûn'a müracaatta bulunarak, ödemeleri gereken tüm vergilerini ödemelerine rağmen, yöneticiler tarafından "tekâlif-i şakka" namıyla vergi istenildiğini söyleyerek haksızlığın giderilmesini istemişlerdir. Haksızlığın giderilmesi için 16 Nisan 1751 tarihinde Amid kadısına hüküm gönderilmiştir. ${ }^{145}$ Amid halkından Seyyid Mehmet, Seyyid Mustafa, Seyyid Bektaş vesair kimseler divana başvurarak, imdad-ı seferiye, imdad-ı hazeriye ve avârız vergilerinden hisselerine düsseni tamamen ödemelerine rağmen, yöneticiler tarafından tekâlif-i şakka namıyla vergi istendiğinden şikâyetçi olmuşlardır. Meselenin halledilmesi ve usulsüz vergi taleplerinin reddedilmesi için 18 Temmuz 1767 tarihinde Amid kadısına hüküm yazılmıştır. ${ }^{146}$

Konu edilen dönemde halktan usulsüz şekilde tahsil edilmek istenen tekâlif-i şakka vergisinin hangi adlar adı altında istendiğinde dair 23 Mart 1769 tarihli bir olayda Garb-ı Amid Nahiyesi'ne tabi Çarugi karyesi halkı, yöneticiler tarafından tekâlif-i şakka namıla kendilerinden çeşitli vergiler istenildiğinden bu sebeple karyelerinin "halinin harap" halkın durumunun ise "perakende ve perişan" olduğunu söyleyerek divana şikâyette bulunmuşlardır. Halktan tekâlif-i şakka vergisinin alınmaması için Diyarbekir valisine ve Amid kadısına emir gönderilmiştir. ${ }^{147}$ Yine Amid kazâsı'na bağlı Şeyh Höbek, Tezvek, Dergâh, Süleyman karyeleri halkı 26 Ocak 1782 tarihinde Dîvân-ı Hümâyûn’a müracaat ederek, vergilerini tamamen ödemelerine rağmen, yöneticiler tarafından tekâlif-i şakka namıyla vergi istendiğini bu

\footnotetext{
140 Kazıcı, Osmanlılarda Örfi Vergiler ve Bu Vergilerin Kaynağı Olan Örfi Hukuk, s. 290-291.

141 Ünal, Osmanlı Tarih Sözlüğü, s. 675-676.

142 BOA. A. DVNSAHK. DB. d.1, 2, 3, 6, 94, 151, 207; BOA. A. DVNSAHK. DB. d.3, s. 172; BOA. A. DVNSAHK. DB. d.4, s. 55, DŞS. 348, s. 29.

143 BOA. A. DVNSAHK. DB. d.1, s. 2.

144 BOA. A. DVNSAHK. DB. d.1, s. 6.

145 BOA. A. DVNSAHK. DB. d.1, s. 207.

146 BOA. A. DVNSAHK. DB. d.3, s. 172.

147 "Emr-i âlî-şânımlavârid olan tekâlife dahi edâda kusurları yoğken bilâ-fermân tekâlif-i şakka namıyla mübaşiriye ve çayur akçesi vesair bahane ile ehl-i örf tarafından rencide ve teâddîeyledüklerinden karye-i mezbûrun hali harab ve reâyaları perakende ve perişan olduklarından mal-1 mirilerinden girü noksan bir nesne malları olmamalarıyla ol emr-i şerifim ile vârid olan tekâlifi edâ eylediklerinden sonra bilâ-fermân tekâlif-i şakka namıyla gedük akçesi, gedük çayır ve kervan akçesi vesair mezâlim ile ehl-i örf tarafindan rencide ve remîdeitdirilmeyüb...", DŞS. 348, s. 29.
} 
sebeple karye halkının zor durumda kaldığını söylemişlerdir. ${ }^{148}$

Vergiler hususunda arşiv vesikalarına yansıyan şikâyet örneklerinden görüleceği üzere XVIII. yüzyılda Amid kazâsı'nda halkın en çok şikâyet ettiği konuların başında fazladan vergi talepleri ve vergiden muaf zümrelerden usulsüz vergi taleplerinin olduğu anlaşılmaktadır. Amid halkının fazladan vergiler hususundaki şikâyetlerinin başında tekâlif-i şakka, ispenç, öşr ve bac vergileri ön plan çıkarken, vergiden muaf zümrelerin şikâyetlerinin temel sebebini bu kimselerden alınmak istenen resm-i râiyyet, avârız, adet-i ağnam ve tekâlif-i şakka vergileri oluşturmaktadır. XVIII. yüzyılda ekonomik, siyasi, sosyal alanlarda yaşanan olumsuzlukların özellikle vergiler hususunda halk üzerinden yeni arayışlara yol açtığı, yönetici zümrenin hiçbir hukuki dayanağı olmayan tekâlif-i şakka vergisi adı altında ekonomik düzenin bozulduğu bu dönemde kendilerine ekonomik çıkar sağlamaya çalıştıkları anlaşılmaktadır. XVIII. yüzyıla ait arşiv vesikalarından Amid halkının gerek kendilerinden alınmak istenen fazladan vergi talepleri, gerekse vergiden muafiyeti bulunan kimselerden usulsüz vergi istenmesi hususunda Dîvân-ı Hümâyûn'u sıkça ziyaret ettikleri görülmektedir. İmparatorluğun her bölgesinde olduğu gibi Amid kazâsı'ndangelen şikâyetlerin dikkate alındığı ve bu şikâyetlere azami ölçüde adaletle çözüm aramaya çalıştığı anlaşılmaktadır.

Amid kazâ merkezi ve kırsalında vergiler ile ilgili anlaşmazlıklar sadece yönetici sınıfın usulsüz veya fazladan vergi taleplerinden kaynaklanmamıştır. Halkın vergilerin ödenmesi esnasında başvurduğu çeşitli usulsüzlükler de yönetici sınıfı iktisadi anlamda zor durumda bırakmıştır. ${ }^{149}$ Mesela Amid kazâsı'na tabi Yaraş, Hönek ve Şavinler karyeleri zabiti olan Ahmet Alemdar Dîvân-ı Hümâyûn'a müracaat ederek, kendi tasarrufunda bulunan karyelerin halkının öşür vesair vergileri ödemeye yanaşmadıklarını söyleyerek şikayetçi olmuştur. Verginin halktan tahsil edilmesi ve halkın muhalefet etmemesi için 31 Eylül 1741 tarihinde Diyarbekir valisine hüküm yazılmıştır. ${ }^{150}$ Yine Garb-i Amid Nahiyesi'ne bağlı Selimi Mezraası'nda senelik altı bin akçe tîmâra sahip olan Yusuf adlı sipahi, sahibi olduğu yerlerden hâsıl olan beşte bir öşürleri halktan almak istediğinde, bazı kimselerin öşürlerini ödemeye yanaşmadıkları ve çeşitli bahane ürettiklerini söyleyerek 9 Nisan 1749 tarihinde Dîvân-ı Hümâyûn’a başvurarak şikâyetçi olmuştur. ${ }^{151}$ Şark-i Amid Nahiyesi'ne bağlı Kıtırbil-i Süfla karyesinde senelik on iki bin beş yüz yedi akçe tîmâra müşterek sahip olan Abdullah, Hasan, İbrahim, Hüseyin adlı sipahiler Dîvân-ı Hümâyûn'a müracaat ederek, sahibi oldukları karyenin gayrimüslim halkından Ebrak oğlu Yakob, Samashatir oğlu Beșan, Haciros'un oğulları Estefo ve Perovişmas, Görgis, Masarlo oğlu Eydo ve Yarsum ödemeleri gereken öşür ve ispenç vergilerini ödemeye yanaşmadıklarından sipahiler öşür ve ispenç vergilerinin taraflarına alınmasını istemişlerdir. Meselenin halledilmesi için 22 Mart 1756'da Amid kadısına hüküm gönderilmiştir. ${ }^{152}$ Amid

\footnotetext{
148 BOA. A. DVNSAHK. DB. d.4, s. 55.

149 BOA. A. DVNSAHK.DB.d.1, s. 158; BOA. A. DVNSAHK. DB.d.2, 32, 44, 45, 57, 61, 93, 114; BOA. A. DVNSAHK. DB. d.3, 32, 60, 95, 113, 293, 333, 383.

150 'karye-i mezbûrreâyalarının üzerlerine edâsı lazım gelen aşar-1 şer'iyyevesair hukuk ve rüsumatları kanun ve defter mucibince talep eyledikteashab-1 ağraz ve mütegallibeden bazı kimesneler kendü hallerinde olmadıklarından naşi... ve kanun ve defter mucibince ahz u kabzına muhalefet ve ziyade gadr ve teâddîden hali oldukları...", BOA. A. DVN. ŞKT. d. 1007, s. 29.
}

151 BOA. A. DVNSAHK. DB. d.1, s. 158.

152 "Zimmî râiyyet ve râiyyet oğullarından üzerlerine edâsı lazım gelen resm-i ispençleriyle karye-i mezbûre toprağında zirââtlarıyla hâsıl eyledikleri terekelerinden dîvân tarafina ait olan bește bir öşürlerini taleb ve almak murad eylediklerinde mesfûrlar birbirleriyle yekdil ve mücerred ve yine karye-i mezbûre zimmî reâyalarından debbağ tâifesinden bazı âdemlerine bazı zimmîlere istinaden üzerlerine edâsı lazım gelen resm-i ispençlerin ve 
halkından sipahi Ali sahibi olduğu bağlardan elde edilen üzümlerden öșür almak istediğinde halktan bazı kimselerin "ol bă̆ ve esbabların ashabı bizim mülklerimizdir bağlarımızın üzümlerinden öşr-i malların resm ve kadîm-i esbablarımızın dahi defter-i hakâni mucibince resm virmeziz" diyerek vergi vermeye muhalefet etmelerinden dolayl 6 Ağustos 1757'de dîvân-ı hümâyûn'a müracaat ederek şikâyetçi olmuştur. ${ }^{153}$ Garb-i Amid Nahiyesi'ne tabi Taş ma'a Mezraa-i Balalur(?) adlı karyede otuz sekiz bin yedi yüz altmış bir akçe zeâmete sahip Abdullah adlı zaim 30 Ocak 1777 tarihinde Dîvân-ı Hümâyûn'a şikâyette bulunarak, 1776 ve 1777 yıllarına ait olan mahsul ve vergilerini almak istediğinde, karye halkının dışarıdan bazı kimseler ile bir olarak ödemeye yanaşmadıklarından, mahsulat ve diğer vergilerinin kendisine alınmasını istemiştir. ${ }^{154}$

Görüldüğü üzere XVIII. yüzyılda yönetici sınıfın vergiler hususunda en sık şikâyet ettiği meseleler halkın vergi vermeye yanaşmaması veya vergiyi eksik ödemek istemesi gelmektedir. İncelenilen dönemde Amid kazâsı'ndaki yönetici zümre arasında vergiler hususunda başı çeken kesim tîmâr ve zeâmet sahipleridir. Dirlik sahipleri tasarrufları altındaki topraklardan elde ettikleri ürünlerden öșür almak istediklerinde halk tarafindan muhalefete uğramakta bu durum dirlik sahiplerinin ekonomik durumunu bozarak halk ile dirlik sahipleri arasında önemli meselelere yol açmaktadır. XVIII. yüzyılda Amid kazâsı'ndaki yöneticilerin vergiler hususunda halk ile yaşadığı meselelerin tamamı karyelerde meydana gelmekte ve bu meselelerin genellikle öşür vergisi kaynaklı olduğu anlaşılmaktadır. Bu dönemde, halktan usulsüz veya fazladan vergi taleplerinde olduğu gibi dirlik sahiplerinin de haklarını korumak için devletin önemli rol üstlendiği görülmektedir.

\section{0-Nakil ve İskân}

XVIII. yüzyılda Amid kazâ merkezi ve karyelerde meydana gelen olaylardan bir diğeri halkın bağlı bulunduğu araziyi terk etmesi sebebiyle toprak üzerinde mülkiyet hakkına sahip kimselerin zor durumda kalması veya sipahilerin halkı mukim oldukları yerden kaldırarak başka bir yere naklederek orada iskân etmeye zorlaması gibi olaylardır.

Osmanlı Devleti'nde halkın bağlı bulunduğu toprağını terk etmesi yasaktır. Sipahi, toprağını terk eden halkı takip etme ve toprağına geri getirme hakkına sahip olmasına rağmen, toprağın terk edilmesinin üzerinden on yıl geçmişse, artık toprağa bağlılığı sona erer ve halkın geri getirilmesi gerekmezdi. Şehirde on yıl yaşayan halk artık şehir halkından sayılarak tahrir defterlerine kaydedilmezdi. ${ }^{155}$ Ancak halkın bağlı bulunduğu tımârını terk etmesi sipahinin gelirinin azalmasına dolayısıyla askeri mükellefiyetlerini yerine getirememesine yol açmakta, bu durum dolaylı yoldan devleti zarara uğratmaktadır. ${ }^{156}$

zirââtlarıyla hâsıl eyledikleri terekeleri öşürlerinden dîvân tarafina ait olan beşte bir öşürlerini virmeğetaâllül ve muhalefet ve tîmârları mahsulünü küll-i gadr eylediklerin bildirüb...” BOA. A. DVNSAHK. DB. d.3, 44, s. 61 .

153 BOA. A. DVNSAHK. DB. d.2, s. 114.

154 BOA. A. DVNSAHK. DB. d.3, s. 293.

155 Durmuş Volkan Karaboğa, “Klasik Dönemde Osmanlı Devleti’nde Tarım”, Süleyman Demirel Üniversitesi Sosyal Bilimler Enstitüsü (Yayımlanmamış Yüksek Lisans Tezi), Isparta 2010, s. 14.

156 Gül Akyılmaz “Osmanlı Devleti’nde Reâya Kavramı ve Devlet-Reâya İlişkileri”, Osmanlı, Yeni Türkiye Yayınları, Ankara 1999, IV, s. 42; Gül Akyılmaz, “Osmanlı Devleti’nde Yönetici Sınıf- Reâya Ayrımı”, GÜHFD, 8(1-2), Ankara 2004, s. 1-20. 
Halkın defterde kayıtlı toprağından kalkarak başka bir bölgeye ziraat veya başka bir uğraş için göç etmesi toprak denetçisi durumundaki kişilerin sıkça şikâyet ettiği konulardan biridir. Aynı zamanda göç eden kişi veya kişilerin eski yerlerine kanuna aykırı şekilde tekrar iskân edilmek istenmesi de sıkça karşılaşılan bir durumdur. Amid kazâ merkezi ve karyelerde bu şikâyetler ile ilgili birçok örnek bulunmaktadır. Mesela Amid kazâsı'na tabi Ekrek karyesinin zimmî halkı kırk sene önce Amid kazâsı'na göç etmelerine rağmen, karyelerinin sipahileri olan Bayram, Hüseyin, Ali ve Mehmet'in kendilerini tekrar eski karyelerine nakil ve iskân etmek için rahatsızlık verdiklerini söyleyerek 10 Haziran 1746 tarihinde Dîvân-ı Hümâyûn'a başvurmuşlardır. ${ }^{157}$ Yine Şark-i Amid Nahiyesi'ne tabi Satıkendi karyesinin Müslüman ve gayrimüslim halkı da kendilerinin on sene önce Amid kazâ merkezine göç ettiklerini ancak eski karyeleri olan Satıkendi karyesi sipahilerinin" sizi kadîm-i karyeye iskân nakl ve kaldurmak lazımdur" diyerek haksız müdahale ettiğini söylemişlerdir. Sipahilerin kanuna aykırı taleplerinin men edilmesi için 29 Aralık 1750 tarihinde Diyarbekir valisine ve Amid monlasına hüküm gönderilmiştir. ${ }^{158}$

Gündelik hayat içerisinde halkın kanuna aykırı şekilde nakil ve iskân ettirilmek istenmesi halk ve sipahiler arasında sorunlara sebep olduğu gibi, halkın bağlı olduğu toprağı izinsiz terk etmesi de toprak denetçisi durumundaki sipahileri zor durumda birakmakta ve gündelik hayatta çeşitli sorunlara neden olmaktadır. Mesela Şark-i Amid Nahiyesi'ne bağlı Kıtırbil-i Süfla karyesinde senelik on iki bin yetmiş yedi akçe tîmâra müşterek sahip olan Ebubekir, Hasan, Hüseyin ve İbrahim adlı sipahiler mutasarrıf oldukları karyenin gayrimüslim halkının izinsiz şekilde başka yere göç ettiklerinden, gayrimüslim halkın eski karyelerine nakledilmelerini talep etmişlerdir. Sipahilerin isteklerinin karşılanması ve yerlerini terk eden halkın eski yerlerine nakledilmesi için 16 Kasım 1755 tarihinde Amid kadısına hüküm yazılmıștır. ${ }^{159}$ Yine Şark-i Amid Nahiyesi'ne tabi Teymürhan karyesi sipahisi Abdullah, karye halkından bazı kimselerin karyelerini izinsiz terk ettiklerini bu sebeple vergi alamadığından zarara uğradığını söyleyerek Dîvân-ı Hümâyûn'a şikâyette bulunmuştur. Karyelerini terk eden halkın eski yerlerine tekrar nakil edilmesini istemiştir. Sipahinin şikâyeti sebebiyle yerlerini terk eden halkın eski yerlerine nakil ve iskân ettirilmeleri için 10 Nisan 1756'daAmid kadısına hüküm yazılmıștır. ${ }^{160}$ Beşir ve Osman adlı sipahiler 19 Aralık 1760 tarihinde divana müracaat ederek, sahibi oldukları yerlerin halkından bazılarının başka yere göç ettikleri, halkı eski yerlerine tekrar nakil ve iskân etmek istediklerinde halk tarafından çeşitli bahane ve muhalefet ile karşılaştıklarını söyleyerek şikâyetçi olmuşlardır. ${ }^{161}$

Görüldüğü üzere halkın izinsiz şekilde toprağını terk etmesi veya yöneticilerin kanuna aykırı şekilde halkı mukim oldukları yerden başka bir yere zorla nakletmek istemesinin yöneticiler ile halk arasında önemli sorunlara sebep olduğu anlaşılmaktadır.

157 "Ekreknâm karyenin defterinden mukayyet râiyyet ve râiyyet oğullarından iken bundan akdem karye-i mezbûredenkalkubvarub kırk seneden mütecaviz Amidkazâsında sakin ve üzerlerine edâsı lazım gelen resm-i ispençleri kanun ve defter mucibince karye-i mezbûre sipahilerine edâidüb kanuna müteallik on sene bir yerde sakin olan reâyayıkaldurmak teklifi ile teâddî ve rencide olunmak icab itmez iken...” BOA. A. DVNSAHK. DB. d.1, s. 87.

158 BOA. A. DVNSAHK. DB. d.1, s. 199.

159 BOA. A. DVNSAHK. DB. d.2, s. 44.

160 BOA. A. DVNSAHK. DB. d.2, s. 54.

161 "Defterlüreâyalarınbazuların mahallerinden kaldırılubkadîm-i karyelerine nakl ve iskân murad eylediklerin hilâf-1 kanun ve defter taâllül ve muhalefet ve ol-veçhile mukataa-i mezbûr mahsulüne küll-i gadr..." BOA. A. DVNSAHK. DB. d.2, s. 222. 
Amid karyelerinden güvenlik, ekonomik vb. sebepler ile kazâ merkezine yerleșen insanlar karyelerdeki sipahilerin vergi kaybetmesine sebep olmakta bu durum kırsaldaki sipahileri ekonomik yönden olumsuz etkilemektedir. Sipahilerin kanuna aykırı nakil taleplerinin de uzun süre önce Amid kazâ merkezine yerleşmiş olan halkı zor duruma soktuğu görülmektedir. Arşiv vesikalarından devletin, Amid kazâ merkezi ve karyelerinde usulsüz nakil talepleri ile halkın toprağını izinsiz terk etmesine müsaade etmediği yönetici veya halk ayrımı yapmadan bu türlü şikâyetlere adaletle çözüm aradığı anlaşılmaktadır.

\section{1-Diğer Olaylar}

Amid kazâsı ve kırsalında gündelik hayatta meydana gelen olaylardan bir diğeri de toplumsal düzeni bozucu hareketlerdir. Bir asır boyunca kazâ merkezi ve karyelerde meydana gelmiş iki hırsızlık vakası, üç mahalleden ihraç vakası tespit edilebilmiştir. Kamu düzenini bozan bu eylemler, elbette ki verilen örnekler ile sınırlı olmayıp, mevcut belgeler dâhilinde fikir edinilmesi açısından önemlidir.

Gündelik hayat içerisinde Osmanlı yöneticilerinin üzerinde önemle durduğu konuların başında, genel güvenliğin sağlanması gelmektedir. Bu sebeple Osmanlı'da en küçük idarî birim olan mahalle veya karye sakinleri arasında ortak sorumluluk bilincinin oluşturulması önem arz etmiştir. Şehir içi güvenlik söz konusu olduğunda, bunu sağlamak amacı ile alınan önlemlerin başında, mahallelerde veya karyelerde ikâmet edenlerin birbirlerine karşılıklı olarak kefil tutulmaları hususu olmuştur. Bunun doğal bir sonucu olarak toplum içinde sosyal kontrol mekanizması gelişmiştir. ${ }^{162} \mathrm{Bu}$ sebeple insanların toplu halde yaşadığı mahalle ve karyelerde toplumsal düzeni bozucu olumsuz hareketlere müsaade edilmemiş, bu hareketleri yapanlar mahalleden ihraç edilmişlerdir.

Amid kazâsı'nda mahalleden ihraç vakaları şöyle gelişmişti. Mesela Mehmet Paşa Mahallesi'nden Mehmet Ağa oğlu İsmail Efendi 4 Eylül 1723'de mahkemeye başvurarak, mahallelerinde ikâmet eden Halil'in içki içip sarhoş bir şekilde evinin önünde ve sokakta bağırıp çağırdığını ve mahalle ahalisini taciz ettiğinden mahalleden gönderilmesini talep etmiştir. Mahkeme Halil'e hakkındaki iddiaları sormuş, Halil kendisine yöneltilen iddiaları reddetmesine rağmen, mahalle halkının ifadeleri yerinde bulunarak mahalleden ihraç edilmiștir. ${ }^{163}$ Gayblar Mahallesi'nden İbrahim oğlu Mustafa, Ali oğlu Mehmet, Mustafa oğlu Ebubekir, 13 Ekim 1723 tarihinde mahkemeye başvurarak, mahallelerinde yaşayan Fatma Hanım'ın evine yabancı erkekleri aldığı, bu sebeple mahalle halkının rahatsız olduğunu söylemişlerdir. Mahkeme, mahalle imamı Ahmet Efendi ve halkın ifadelerine binaen Fatma Hanım'ın mahalleden gönderilmesine hükmetmiştir. ${ }^{164} \mathrm{Bu}$ olayda halkın mahkemedeki ifadesinin güvenilirliğini artırmak amacıyla mahalle imamı Ahmet Efendi'nin de şahitlik ederek ifade vermesi ilginçtir. Mahalleden ihraç ile ilgili başka bir hadise de Kubad Bey

162 Özen Tok, Kadı Sicilleri Işı̆̆ında Osmanlı Şehrindeki Mahalleden İhraç Kararlarında Mahalle Ahalisinin Rolü (XVII ve XVIII. Yüzyıllarda Kayseri Örneği), Erciyes Üniversitesi, Sosyal Bilimler Enstitüsü Dergisi, Sayı: 18, Kayseri 2005, s. 156.

163 "Mezbûr Halil fesekadanolubşürb-i hamridüb menzilinde ve kapısı kurbundavâki sokak başında leylen ve neharen türkü çağırıbmürûr ve ubûr iden ibâdullahınehl-ü ıyâlineevza ve taarruz eylediği...” DŞS. 592, s. 6.

164 "Mezbûr Mustafa ve Mehmet ve Ebubekir her biri kendi rrzlarıyla mukayyedolub husus-u mezbûr iş bu mezbûrunaisnad ve mahz-1 iftira olduğunu ve müdde'iye-i mezbûrefatıma daima na-mahrem olan kimesneleri kendi menziline getirüb bu makule ef'al ile muttasıfa olubmezbûrfatımanınef'al ve ahvâlinden hoşnud ve razılar değilleriz mahalle-i mezbûreden ihraç olunsun..." DŞS. 592, s. 48. 
Mahallesi'nden Mustafa evine uygunsuz kadınları getirdiğinden, Mustafa'nın hanımı Emine Hatun ve mahalleden bazı kimselerin şikâyeti üzerine 19 Mayıs 1739 tarihinde yapılan mahkeme neticesinde Mustafa'nın mahalleden ihraç edilmesine karar verilmiştir. ${ }^{165}$

Yukarıdaki örneklerde görüldüğü üzere Amid kazâsı'nda meydana gelen üç mahalleden ihraç olayının ikisi eve yabancı kadın veya erkeklerin alınması sebebiyle halkın rahatsız olmasından kaynaklanırken, bir olayda sarhoşluk ve gürültü çıkarılması nedeniyle mahalle halkının bu durumdan rahatsızlığından ileri gelmiştir. Mahalleden ihraç kararlarında halkın toplu şekilde ifadelerine binaen Amid mahkemesinin olayı derhal sonuca bağlaması dikkat çekmektedir.

XVIII. yüzyılda Amid kazâsı'nda toplumsal düzeni bozan diğer bir eylem hırsızlıktır. Arşiv vesikalarına yansıyan iki hırsızlık vakası tespit edilebilmiştir. Küçük Kinisa Mahallesi'nden Aron ve Osib, 3 Aralık 1740'da mahkemeye başvurarak, İvaz ve Kamo adlı şahısların gece vakti Osib'in evine girerek küplerini kırdıkları, Aron'un evinden iki halı ve bir bohça çaldıklarından çalınan malların geri alınması ve adaletin sağlanmasını talep etmişlerdir. ${ }^{166}$ Yine Şark-i Amid Nahiyesi'ne tabi Akviran karyesinden Hacı Mahmut oğlu Seyyid Ömer 26 Şubat 1747 tarihinde mahkemeye başvurarak, Hani Kazâsı'na tabi Hamenek(?) karyesinden Hacı Osman oğlu Mehmet, Serkü oğlu Ogo ve kardeşi Erkü'nün gece vakti evinin duvarını delerek 442 kuruşluk eşya ve nakit parasını çaldıklarını söyleyerek şikâyetçi olmuştur. Mahkeme esnasında karye ahalisinden bazı kimselerin ifadeleri ile Erkü, Ogo ve Hacı Osman oğlu Mehmet suçlarını kabul etmişlerdir. ${ }^{167}$ Görüldüğü üzere arşiv vesikalarına yansıyan iki hırsızlık olayının biri kazâ merkezinde diğeri karyede meydana gelmiştir. Bu olayların sayısının az oluşu konu hakkında genel bir değerlendirme yapılmasını güçleştirmektedir. Ancak mahkemeye yansıyan her iki olayda da devletin adaletin tesisi için çaba sarf ettiği ve hırsızlık olaylarının aydınlatılabilmesi için gerektiğinde bölge halkının ifadelerine başvurduğu görülmektedir.

\section{Sonuç}

Amid kazâsı ve çevresinde gündelik hayatta şikâyete konu olan gasp, darp, cinayet, hırsızlık, fuzuli müdahale, alacak-verecek meseleleri, su-arazi anlaşmazlıkları, vakıflarda meydana gelen usulsüzlükler ve haksız vergi talepleri gibi birçok hadisenin meydana geldiği arşiv vesikalarından tespit edilmiștir. Bu tür olaylarda Amid halkının hakkını arayabilmek için Amid kadısına başvurduğu veya gerektiğinde Dîvân-ı Hümâyûn'a arz-ı hâl sunduğu görülmektedir. Amid kazâsı ve çevresinde eşkıyalık vakalarının arttığı bu sebeple kazâ merkezi ve karyelerde yașayan insanların bireysel veya toplu yapılan eșkıyalık hareketleri sebebiyle zor durumda kaldıkları anlaşılmaktadır. Bu dönemde devletin, eşkıyayı ve zorbaları bertaraf edebilmek için büyük çaba sarf ettiği ve bu sebeple merkezden Amid kazâsı yöneticilerine sık sık fermanlar gönderildiği tespit edilmiştir. Bu dönemde devletin içinde bulunduğu ekonomik kriz/darlık nedeniyle vergiler hususunda vergi veren halk ile vergi tahsildarları arasında da sıkça sorunlar meydana geldiği anlaşılmaktadır. Bu meseleler tek taraflı olmayıp vergi verenler ile vergi alan kesimin farklı haksızlıklarından kaynaklanmaktadır. Bu dönemde

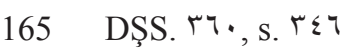

166 DŞS. rฯ., s. r०५.

167 DŞS. rIT, s. Irq.
} 
Amid kazâsı'nda kanuna aykırı vergi talepleri ile halkın vergi ödemeye yanaşmaması en önemli meseleler olarak ön plana çıkmaktadır.

18. yüzyılda devletin içinde bulunduğu siyasi, sosyal ve ekonomik durumunAmid kazâsı'ndaki vakıflara da doğrudan veya dolaylı şekilde yansıdığı anlaşılmaktadır. Nitekim belgelerde vakıflardaki bozulmalara ve bu bozulmalara karşı halkın ve vakıf yöneticilerinin tavırları açık şekilde görülmektedir. Kazâ genelindeki şikâyetler arasında alacak verecek davalarının önemli bir yer tuttuğu ancak bu davaların genellikle iki kişi arasındaki basit alacak-verecek konularını ihtiva ettiği anlaşılmaktadır.

Kazâda yaşanan diğer bir olayın arazi ve su anlaşmazlıkları olduğu görülmektedir. Özellikle arazi davalarının sebebi kişilerin tasarrufundaki yerlere müdahale ile olurken, su ile ilgili şikâyetlerin kişi veya kişilerin tasarrufundaki suyun yerinden çevrilmesi sebebiyle kişi veya kişilerin mağduriyetinden kaynaklandığı görülmektedir. Yine kazâ genelinde önemli sayıda miras şikâyetinin olduğu, bu davaların ana sebebinin kişilerin hissesine düşen miktara kanaat etmemesi veya miras hissesini alamamasından ileri geldiği görülmektedir.

Konu edilen dönemde kazâ genelinde nakil ve iskân ile ilgili şikâyetlerin gündelik yaşam içerisinde önemli sorunlara sebep olduğu görülmüştür. Bu şikâyetlerin temel sebebinin kişi veya kişilerin bulundukları arazilerini sebepsiz terk etmesinden ileri geldiği gibi, uzun süre önce göç etmiş kişi veya kişilerin eski yerlere nakil ve iskân edilmek istenmesi de bu sorunlara sebep olabildiği arşiv vesikalarından görülmektedir.

Sonuç olarak; XVIII. yüzyılda devletin içerisinde bulunduğu sosyal, siyasi ve ekonomik durumunAmid kazâsı'na farklı alanlarda etki ettiği görülmüştür. Amid halkının yaşadığı her türlü meselede Divan-ı Hümâyûn'a sıkça başvurduğu ve devletin de şartların elverdiği ölçüde bölgede adalet ve düzenin sağlanmasına çalıştığı anlaşılmaktadır.Osmanlı Devleti'nin içinde bulunduğu şartlara rağmen bu şikâyetlere çözüm aramaya çalışması devletin adalet ve huzura verdiği önemin de bir göstergesi olarak görülmelidir. 


\section{Kaynakça}

Başbakanlık Osmanlı Arşivi, Diyarbakır Ahkâm Defterleri: 1, 2, 3, 4, 5.

Başbakanlık Osmanlı Arşivi,Diyarbakır Şeriyye Sicilleri: 313, 360, 592, 352, 599, 348, 626, 363, 327, 349, 364, 315, 359.

Başbakanlık Osmanlı Arşivi,Divan-ı Hümayun Sicilleri, Şikâyet Defterleri:83, 100, 67, 74, 32, 62, 39, 1003, 80, 1006, 987, 105, 86.

Başbakanlık Osmanlı Arşivi,Divan-ı Hümayun Sicilleri, Mühimme Defterleri:130, 160, $122,139,86,191,121$.

Başbakanlık Osmanlı Arşivi, Cevdet Zabtiye1874.

Başbakanlık Osmanlı Arşivi, Cevdet Maliye 27989.

Akyılmaz, Gül “Osmanlı Devleti'nde Reâya Kavramı ve Devlet-Reâya İlişkileri”, Osmanlı, Yeni Türkiye Yayınları, Ankara 1999, IV, s. 42; Gül Akyılmaz, "Osmanlı Devleti'nde Yönetici Sınıf- Reâya Ayrımı", GÜHFD, 8(1-2), Ankara 2004, s. 1-20.

Aydın, Mehmet Akif, “Deyn”, DİA, Türk Diyanet Vakfı Yayınları, İstanbul 1995, IX, s. 266.

Bardakoğlu, Ali, “Diyet”, DİA, Türk Diyanet vakfı Yayınları, C.9, İstanbul 1994 s. 473-478.

Barkey, Karen, Eşkıyalar ve Devlet Osmanlı Tarzı Devlet Merkezileşmesi, Çev. Zeynep Altok, Tarih Vakfı Yurt Yayınları, İstanbul 2011.

Bulduk, Abdulgani Fahri, Diyarbakır Valileri, Medrese Yayınları, Ankara 2007.

Cevger, Gürkan, 1 Numaralı ve 1155-1158/1742-1745 Tarihli Karaman Ahkâm Defteri'nin Transkripsiyonu ve Değerlendirilmesi (s.1-60), (Yayımlanmamış Yüksek Lisans Tezi), Atatürk Üniversitesi Sosyal Bilimler Enstitüsü, Erzurum 2012.

Çadırcı, Musa, “Tanzimatın İlanı Sırasında Anadolu'da İç Güvenlik”, TAD, 13(24), Ankara 1980, s. 45-46.

Devellioğlu, Ferit, Osmanlıca-Türkçe Ansiklopedik Lûgat, Aydın Kitabevi, Ankara 2010.

Durmuş Volkan Karaboğa, “Klasik Dönemde Osmanlı Devleti'nde Tarım”, Süleyman Demirel Üniversitesi Sosyal Bilimler Enstitüsü (Yayımlanmamış Yüksek Lisans Tezi), Isparta 2010.

Düzdağ, Ertuğrul Kanuni Devri Şeyhülislamı Ebussuud Efendi Fetvaları, Kapı Yayınları İstanbul 2012.

Ertaş, Fatih Coşkun- Şişman, Bülent, “ XVI. ve XVII. Yüzyıllarda Osmanlı’da Tereke 
Uygulaması ve Muhasebesi-Sosyo-Ekonomik Yapıya ve Miras Hukukuna Etkileri”, MUFITAD, Sayı: 4 İstanbul 2013, s. 199.

Halaçoğlu, Yusuf, XVIII. Yüzyılda Osmanlı İmparatorluğu'nun İskân Siyaseti ve Aşiretlerin Yerleştirilmesi, TTK Yayınları, Ankara 1997.

İlgürel, Mücteba, “Osmanlılarda Eşkıyalık Hareketleri”, DİA, Türk Diyanet Vakfı Yayınları, İstanbul 1995, XI, s. 466-467.

İnalcık, Halil, Osmanlılar Fütuhat, İmparatorluk, Avrupa İle İlișkiler, Timaş Yayınları, İstanbul 2010.

Karaboğa, Durmuş Volkan, “Klasik Dönemde Osmanlı Devleti'nde Tarım”, Süleyman Demirel Üniversitesi Sosyal Bilimler Enstitüsü (Yayımlanmamış Yüksek Lisans Tezi), Isparta 2010.

Karademir, Zafer, “Osmanlı Sosyo-Ekonomik Yaşamında Su: 18.Yüzyıl Eyâlet-i Rum Örneği”, TỉD, 29(1), İzmir 2014.

Kazıcı, Ziya, İslam Tarihi, MÜİFVY, Cilt. 10, İstanbul 1995.

Küçük, Levent, "Osmanlı Vergi Hukukunda Avârız Kavramı ve Avârızın İdaredeki Rolü”, (Yayımlanmamış Doktora Tezi), Ankara Üniversitesi Sosyal Bilimler Enstitüsü, Ankara 2007.

Özcan, Selim, "XVIII. Yüzyılda Canik (Samsun) Sancağında Eşkıyalık Hareketleri”, Osmanlı'dan Günümüze Eşkıyalık ve Terör, Ed. Osman Köse, Samsun İlkadım Belediyesi Kültür Müdürlüğü Yayınları, Samsun 2009, s. 85.

Öztürk, Sait, “Kassâm”, DİA, Türk Diyanet Vakfı Yayınları, İstanbul 1995, XXIV, s. 579.

Pakalın, Mehmet Zeki, Osmanlı Tarih Terimleri ve Deyimleri Sözlügüu, MEB Basımevi, III,İstanbul 1983.

Pamir, Aybars, “İslam ve Osmanlı Hukuku’nda Kasame Müessesesi”, Ankara Üniversitesi Hukuk Fakültesi Dergisi, 54(4), Ankara 2005.

Pamuk, Bilgehan, "XVII. Asır Başlarında Erzurum ve Havalisinde Eşkıyalık Hareketleri”, Osmanlıdan Günümüze Eşkıyalık ve Terör, Ed. Osman Köse, Samsun İlkadım Belediyesi Kültür Yayınları, Samsun 2009, s. 49.

Tok, Özen, Kadı Sicilleri Işığında Osmanlı Şehrindeki Mahalleden İhraç Kararlarında Mahalle Ahalisinin Rolü (XVII ve XVIII. Yüzyıllarda Kayseri Örneği), Erciyes Üniversitesi, Sosyal Bilimler Enstitüsü Dergisi, Sayı: 18, Kayseri 2005.

Uluçay, Çağatay, XVII. Asırda Saruhan'da Eşkıyalık ve Halk Hareketleri, Resimli Ay Matbaası, İstanbul 1944. 
Ünal, Mehmet Ali, Osmanlı Tarih Sözlüğü, Paradigma Yayınları, İstanbul 2011.

Öztürk,Nazif, "Osmanlı Döneminde Vakıflar”, Türkler, Yeni Türkiye Yayınları, Ankara 2002, X, s. 434.

------------, Türk Yenileşme Tarihi Çerçevesinde Vakıf Müessesesi, TDV Yayınları, Ankara 1995.

Yediyıldız, Bahaeddin, XVIII. Yüzyılda Türkiye'de Vakıf Müessesesi, TTK Yayınları, Ankara 2003. 